\title{
Prediction of the appearance of tree of heaven in forest communities in western Slovenia
}

\author{
ANDRAŽ ČARNI1,2 \\ NINA JUVAN MASTNAK ${ }^{3}$ \\ IGOR DAKSKOBLER ${ }^{1,4}$ \\ LADO KUTNAR $^{5}$ \\ ALEKSANDER MARINŠEK ${ }^{5,6}$ \\ URBAN ŠILC ${ }^{1,7}$ \\ ${ }^{1}$ Research Centre of the Slovenian Academy \\ of Sciences and Arts, Institute of Biology, Novi trg 2, \\ 1000 Ljubljana, Slovenia \\ ${ }^{2}$ University of Nova Gorica, Vipavska 13, \\ 5000 Nova Gorica, Slovenia \\ ${ }^{3}$ Research Centre of the Slovenian Academy \\ of Sciences and Arts, Novi trg 2, \\ 1000 Ljubljana, Slovenia \\ ${ }^{4}$ University of Ljubljana, Biotechnical Faculty, \\ Department of Forestry and Renewable Forest \\ Resources, Večna pot 83, \\ 1000 Ljubljana, Slovenia \\ ${ }^{5}$ Slovenian Forestry Institute, Večna pot 2 , \\ 1000 Ljubljana, Slovenia \\ ${ }^{6}$ Higher Vocational College for Forestry and Hunting, \\ Ljubljanska 3, 6230 Postojna, Slovenia \\ ${ }^{7}$ Biotechnical Centre Naklo, Strahinj 99, \\ 4202 Naklo, Slovenia

\section{Correspondence:} \\ Andraž Čarni \\ E-mail: carni@zrc-sazu.si
}

\section{Abbreviation: \\ $\mathrm{TH}$ - tree of heaven \\ (Ailanthus altissima (Mill.) Swingle)}

Keywords: Ailanthus altissima; invasive species; distribution model; traits

Nomenclature: Mala flora Slovenije (1) and Mosses of the Mediterranean (2)

Received September 02, 2016.

Revised October 29, 2017.

Accepted December 29, 2017.

\begin{abstract}
Background and Purpose: Tree of heaven (Ailanthus altissima) is one of the most invasive tree species in Slovenia. Since its invasion into forests is expected, we must raise public awareness and prepare guidelines for forest management in the presence of invasive species. The aim of the research was to predict the potential distribution of tree of heaven, to detect the most endangered forest communities and to discover what characteristics of forest stands make them susceptible.
\end{abstract}

Materials and methods: From databases, literature sources and field observations, we collected all localities in which tree of heaven appears. We assigned these localities geological, geomorphological, soil and climatic data. We then built an ecological model and prepared a map of potential distribution. Based on the modelled future distribution of tree of heaven, we randomly selected and sampled 50 plots in the area in which invasion is expected and outside of this area. We analyzed their morphological and ecological strategies, ecological conditions, origin and social behavior spectrum.

Results: We found that tree of heaven has the largest invasive potential in western Slovenia. The model showed that the most susceptible forest communities appear in warm areas with pronounced climatic seasonality. Many differences occur in floristics and plant traits of forest communities in extreme positions, in terms of susceptibility to invasion, but in transitional areas, these differences are not so obvious, only a higher $p H$ of soil and absence of species characteristic of acidophilus communities are an indicator of vulnerability.

Conclusion: Susceptibility to invasion by tree of heaven is mainly influenced by macro-climatic conditions; in the transitional zone, communities thriving on shallow soils over carbonate bedrock are more vulnerable.

\section{INTRODUCTION}

$\mathrm{T}$

$\mathrm{H}$ which is autochtonous in China was first introduced in Europe

(Paris) in 1751 (3). It was disseminated because of its ornamental value and was also used for afforestation of dry sites, as well as for some economic purposes (e.g. for silkworm breeding) (4). TH is one of the most invasive species in Europe (5). It has a continuous distribution in the Mediterranean area and spreads along a gradient from the meridional to temperate zone (6-8). In Slovenia, it was first recorded in 1875 and is nowadays spread all over the country (9).

This is a typical pioneer woody species that appears in sites with various disturbances. It can often be introduced in an urban environ- 


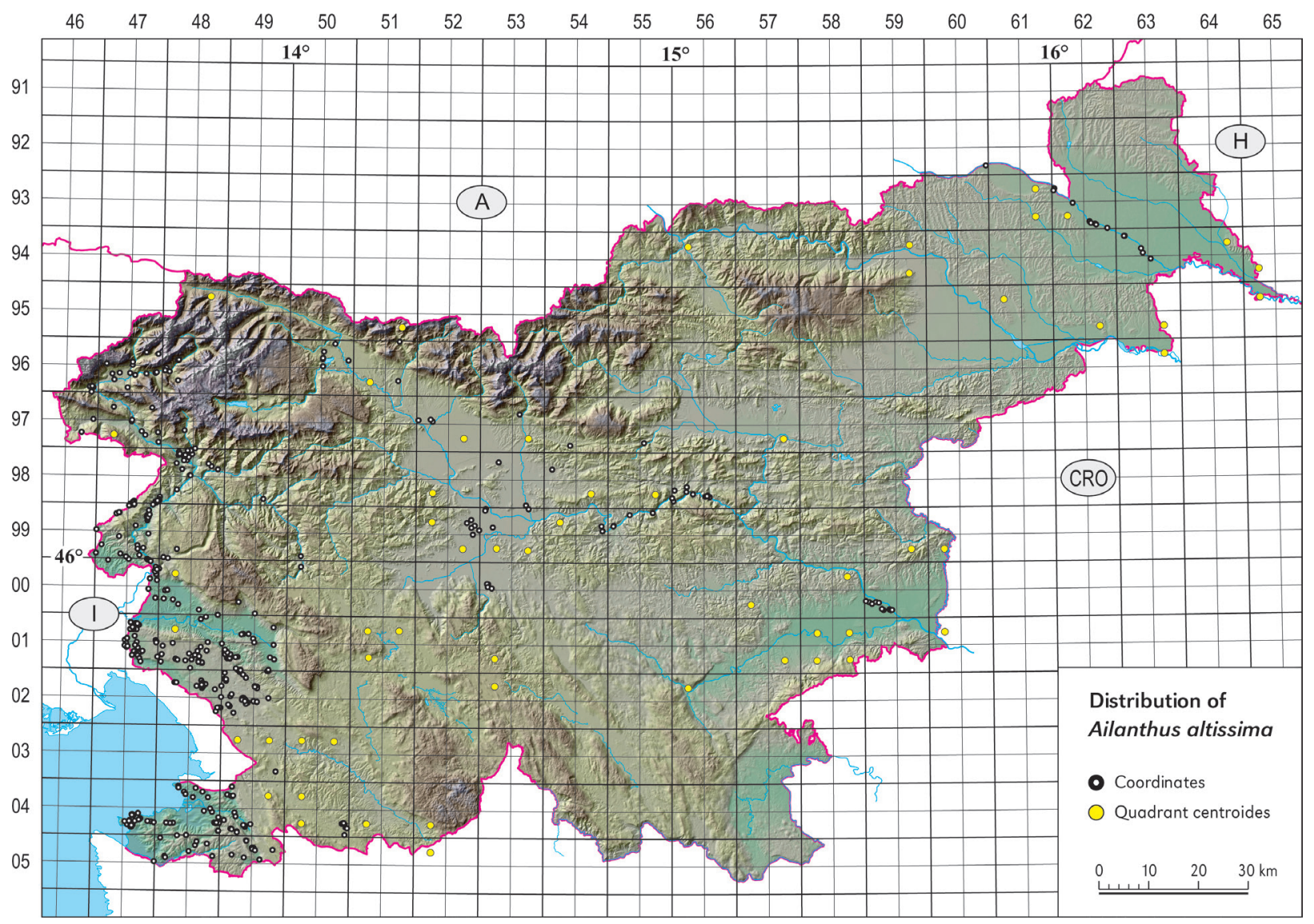

Figure 1. Map of distribution of TH in Slovenia. Localities with exact coordinates are indicated with black and localities presenting centroids of quadrants by yellow points. The data are presented in MTB grid.

ment (10). It is a species of early successional stages that can be found in forest stand gaps or in clearings (11). Its ecological strategy is competitor (12). It is rare in closed stands because it is outcompeted by competitive strong species of late successional stages (13). In the region under research, TH has been observed in sites in pole stages of forest development but not in established forest stands.

Several phases can be distinguished in the mechanism of establishment and dissemination of alien and invasive species (14). The longer an invasive species is present in an area, the more probable it is that it will inhabit all potential habitats. The first phase, the so-called lag phase, is the time between arrival and the beginning of fast growth and spread. Among the reasons for this delay can be considered: a lack of habitats propitious for its settlement, their interdependence with other plants or unsuitable genetic diversity. This phase can last decades, or even centuries, but some species can be invasive immediately.

Intensive studies have been performed in the past to discover how invasive plants, their plant functional types and recipient environment interact, in order to determinate the level of impact (15-17) and to predict the interrelation between an invasive species and the recipient community (18). Plant functional types are a non-phylogenetic grouping of species showing close similarity in their response to environmental and biotic factors (1920). There are two main approaches in the classification of functional types (21); the first is more concentrated on morphological features, such as Raunkier's life forms (22), whereby the morphology of species changes depending on the changing environment. The second approach is based on ecological strategies, for which we used Grime's model of CSR (23). This model is based on how plants or plant communities deal with stress and disturbance. There are main strategies: competitors, stress tolerators and ruderals, and their combinations. The position of each species, as well as of communities, can be determined in a CSR triangle. The community thus gets a functional signature (24).

Since there are still gaps in this knowledge, the aim of our study was to discover which forests are threatened by $\mathrm{TH}$ invasion and what their main characteristics are that make them predisposed to invasion. Our task was to ascertain the present distribution of TH in Slovenia. On the basis of the present distribution of $\mathrm{TH}$ and variables based on geology, geomorphology, soil data and climate, to prepare an ecological model of its potential distribu- 
tion. Our goal was also to discover which forest types are the most endangered by invasion and what makes them vulnerable.

\section{METHODS}

Data on existing locations of TH in Slovenia were collected from databases (25-26) and from available habitat mapping data (27), and some field observations were also done. The locations from databases and field observations were geocoded, while the coordinates from habitat mapping data were calculated as centroids of polygons in which TH occurs. All the coordinates of TH occurrence in Slovenia were integrated into ArcGIS and a map was prepared.

Since TH is distributed only sporadically in eastern and central Slovenia, our research was focused on the western part of Slovenia. A model of TH potential distribution was constructed for this area. In recent decades, modelling techniques have been developed that enable the production of relatively exact maps of the potential distribution of species and communities based on present species localities, environmental factors and accurate modelling techniques (28-29).

The basis for the preparation of the model was data on localities in which TH occurs (346 points) and localities in which TH was not found (1124 points) (29). We assigned to each locality information on bedrock (30), geomorphological conditions extracted from digital model of relief (31), soil type (32) and climate extracted from
WorldClim database (33). As the main transport corridor in the region is valley of the river Soča that correlates with climatic corridor for penetration of the Mediterranean climate towards the Alps, we did not take a transporation network as input data for the analysis. Correlated variables were excluded anyway. In order to ascertain the conditions that allow the appearance of $\mathrm{TH}$ we used the program package WEKA (34-35). Within this program we produced a classification decision tree by using algorithm J4.8. We increased the values of the minimum number of instances in a leaf while other parameters of the algorithm were set to their default values (minimum number of instances in a leaf: 2 , use of unpruned trees: no, confidence factor used in postpruning: 0.25 , subtree raising operation in postpruning: yes, use of binary splits: no). Several potential models were thus obtained. The final selection of the model was based on the qualitative predictive performance estimated with 10 -fold cross validation. The model with the highest percentage of correctly classified instances was selected (Fig. 2).

For visualization of the results and preparation of the map of potential distribution of TH in western Slovenia, we determined in ArcGIS systematic points over the entire selected region at a distance of $100 \mathrm{~m}$. We then used the decision rules of the classification tree to define whether the conditions at a particular point are suitable or unsuitable for TH occurrence. A map of potential distribution of $\mathrm{TH}$ was thus obtained.

In order to determine which are the most endangered forest communities for TH invasion, we first did field sampling. We randomly selected 25 points within the area

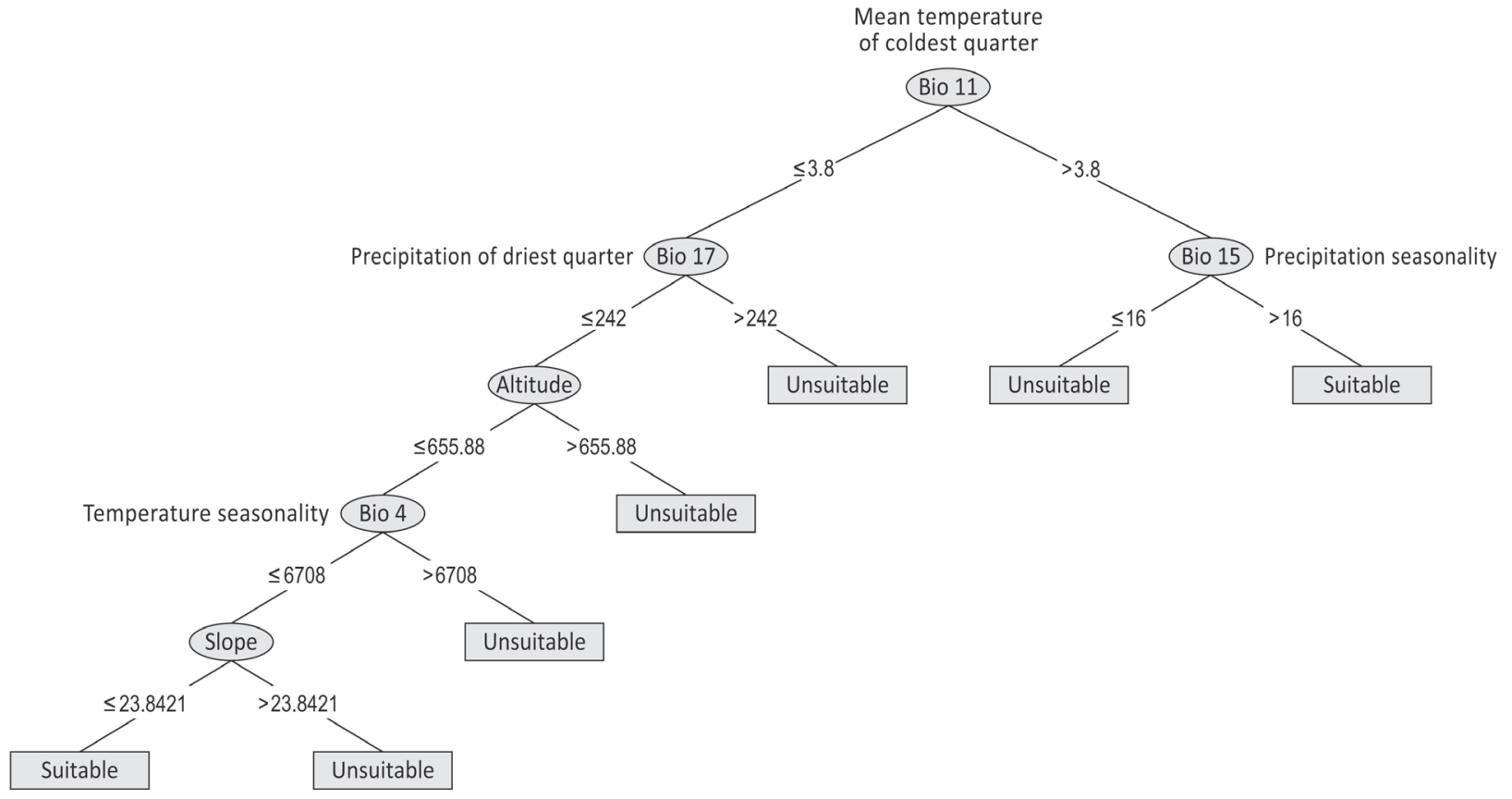

Figure 2. Model prepared by WEKA program. 
of potential distribution of $\mathrm{TH}$ and the same number in the area outside potential distribution of this species. We used the shape of forest surfaces to ensure that points were located within forest (36). On these locations, we sampled $200 \mathrm{~m}^{2}$ large plots according to the standard procedure: floristic inventory of each plot, plant species abundance and cover were estimated by a seven grade scale and the general characteristics of the stand were estimated (37).

We entered the data into the Turboveg program (38) and elaborated them in the program package Juice (39). We then performed clustering, Detrended Correspondence Analysis (DCA) with passively projected bioindicator values, comparison of bioindicator values, chorotypes, morphological and ecological functional types between clusters to detect the floristic, ecological, structural and other features and to discover differences in communities that thrive in the area of potential distribution of $\mathrm{TH}$ and outside. In this way we estimated the characteristics of invaded and non-invaded stands, and from the differences tried to establish the main characteristics that make communities susceptible to invasion of $\mathrm{TH}$.

Floristic similarities among communities were compared using cluster analysis. We eliminated the relevé with SD higher than 2 calculated on the basis of relative Euclidean distance from further analysis. We prepared a dendrogram, in which the original seven graded scale was transformed to percentages and square rooted. We used Euclidean distance and the Ward method for grouping the samples. These data were also subject to Detrended Correspondence Analysis (DCA) prepared in R software (40) using the vegan package (41). Bioindicator values were passively projected onto the two-dimensional ordination space of DCA.

We calculated the characteristic species for each cluster with a fidelity measure and the Fisher test (42). The fidelity measure was set to 0.5 in order for a species to be diagnostic.

In addition to the traditional approach to determine the characteristic features of communities, we also performed analysis of bioindicator values, chorotypes, plant functional types (morphological and ecological) and species behavior types, which reflect the ecological conditions, origin, structure and functionality of communities. We calculated all values on the basis of presence/absence data. The results are presented by Box-plot diagrams and differences between groups were calculated by KruskalWallis test. We used Pignatti ecological bioindicator values reflecting ecological conditions in the community and they were set for each species according to Pignatti (43). The data for the analysis of chorotypes, morphological features and ecological strategies were provided by the BiolFlor database (44), Flora d'Italia (45) and local flora (1).

We also calculated social behavioral type, which is estimated according to the accepted phytosociological placement of each species in the syntaxonomic system (46). Its structure in an individual forest type reflects ecological conditions, dynamics and relationship within the community (47). We considered the following types: species of mesophilous forests Carpino-Fagetea, species of thermophilous deciduous forests Quercetea pubescentis, forest edge Trifolio-Geranietea, dry grassland FestucoBrometea, shrub and mantle species Rhamno-Prunetea, species of acidophilous forests Vaccinio-Picetea and Quercetea roboris and species of forest clearings Epilobietea.

\section{RESULTS}

We collected all available information about appearance of TH and prepared the map of distribution (Fig. 1). It shows that $\mathrm{TH}$ can only be found sporadically in the central and eastern part of Slovenia, mostly along rivers, whereas in the western part of the country, the distribution of $\mathrm{TH}$ is denser.

The model, prediction of which can be accepted with $87.96 \%$ probability, shows (Fig. 2) that the most discriminating variable for identification of $\mathrm{TH}$ habitat is the mean temperature of the coldest quarter (winter). Based on the structure of the model suitable conditions for $\mathrm{TH}$ distribution are there where the mean temperature of the coldest quarter is higher than $3.8^{\circ} \mathrm{C}$ and precipitation occurs seasonally or where the mean temperature of the coldest quarter is lower than $3.8^{\circ} \mathrm{C}$, and the precipitation of the driest quarter (summer) is low, altitude is below 655 meters, temperature seasonality is low and inclination is less than $23.8^{\circ}$.

The model visualization (Fig. 3) showed that TH appears in the south-western part of Slovenia (at the Adriatic coast), below the Karst edge, on the Karstic plateau, in the Vipava Valley and in the southern part of Goriška brda. It is also distributed along rivers in more alpine regions.

The Alnus glutinosa dominated community was eliminated from further analysis, because it was an outlier. The classification (Fig. 4) revealed that relevés can be classified within four clusters (groups). The first and the second groups were mainly sampled in areas in which $\mathrm{TH}$ is potentially distributed, whereas groups 3 and 4 were sampled in the area beyond it.

Figure 5 shows bi-plot of four groups of forest communities with passively projected bioindcator values on first two ordination axes of the DCA analyses. The main gradient is along the first axis, representing the transition between communities classified by cluster 1 , susceptible to invasion of $\mathrm{TH}$, to cluster 4 communities that are not expected to be invaded. The position of clusters 2 and 3 along this axis is not so distinct but they can be distinguished on the second axis.

According to floristic analysis (Tab.1), diagnostic species for clusters 1 and 2 are Hedera helix, Sesleria autum- 


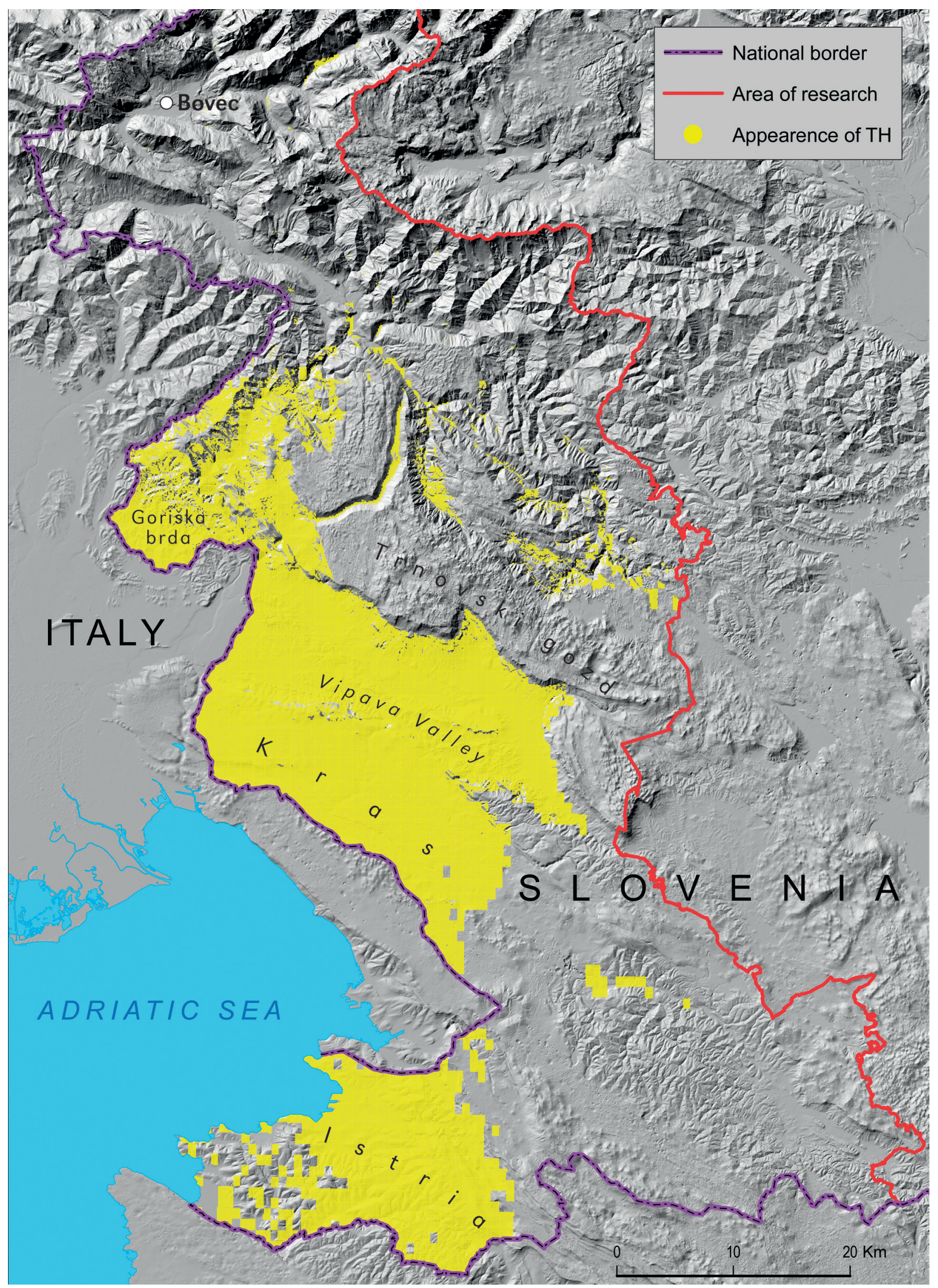

Figure 3. Map of potential distribution of TH in the western Slovenia. 


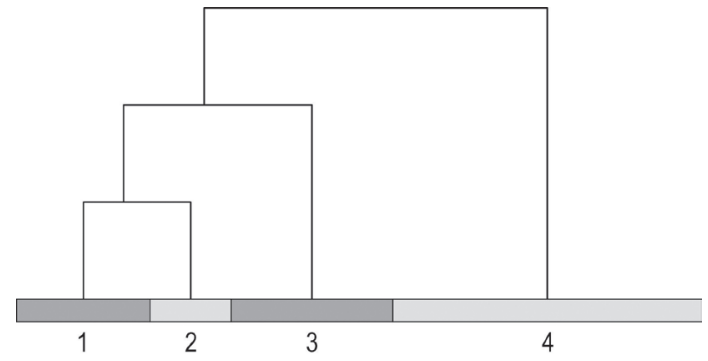

Figure 4. Dendrogram of sampled forest communities revealed four clusters (groups). Clusters 1 and 2 are susceptible for TH invasion and cluster 3 and 4 are not.

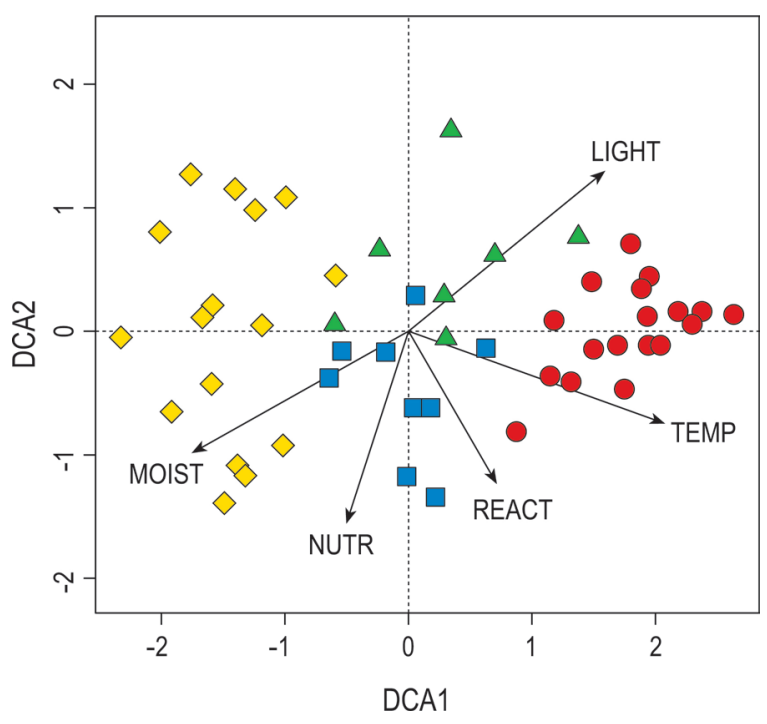

Figure 5. DCA analysis of forest communities with passively projected bioindicator values. Legend: red circles - group 1, blue squares - group 2, green triangle - group 3, yellow diamondgroup 4. Groups correspond to Fig. 4.

nalis and Ruscus aculeatus; diagnostic species for cluster 3 and 4 are Oxalis acetosella, Prenanthes purpurea, Maianthemum bifolium, Athyrium filix-femina and Polytrichum formosum. Diagnostic species for cluster 1 are Cotinus coggygria, Vincetoxicum hirundinaria, Ligustrum vulgare and Crataegus monogyna; for cluster 2 are Asarum europaeum and Galium laevigatum, for cluster 3 are Carex montana, Fragaria viridis, Euonymus europaeus, Festuca heterophylla and Cephalanthera longifolia; and for cluster 4 are Ctenidium molluscum, Cardamine trifolia, Isothecium alopecuroides, Neckera crispa etc.

The dominant tree species in cluster 1 are Carpinus betulus, Quercus cerris, Fraxinus ornus, Pinus nigra, Pinus sylvestris, Robinia pseudoacacia, Quercus petraea, Ostrya carpinifolia and Castanea sativa; in cluster 2 are Fagus sylvatica, Ostrya carpinifolia, Robinia pseudoacacia, Tilia cordata and Ulmus glabra; in cluster 3 are Fagus sylvatica, Castanea sativa, Pinus sylvestris and Quercus petraea; and in cluster 4 are Fagus sylvatica, Picea abies and Abies alba.
The analysis showed clearly that $\mathrm{TH}$ can be expected in forests forming cluster 1, composed of sub-Mediterranean lowland hornbeam forests, secondary black and scots pine forests, turkey oak forests, sessile oak forests and pubescent oak and hop-hornbeam forests. Cluster 2 is still susceptible to TH invasion and is composed of submontane and thermophilous beech forests, as well as ravine forests. Cluster 3, which is less susceptible for TH invasion, is composed of montane beech forests, chestnut forests, sessile oak forests and scots pine forests. Cluster 4 is also less susceptible to TH invasion and is dominated by beech, Norway spruce and silver fir forests. In all these forests the shelterwood management system is applied.

The ecological conditions represented by bioindicator values in these communities are given in Fig. 6. In the cases of light, temperature, humidity and nutrients, a maximum difference $(p<0.001)$ can be found at two extreme positions in cluster 1 and cluster 4, whereas clusters 2 and 3 are in-between. Soil reaction shows that clusters 1 and 2, representing susceptible communities for invasion, show a higher soil reaction than the other two clusters.

The origin of species (Fig. 7) shows that forest communities originating from the Mediterranean area (clusters 1 and 2) are more susceptible to invasion. On the other hand, forests originating from colder areas (boreal, mountains) are less vulnerable.
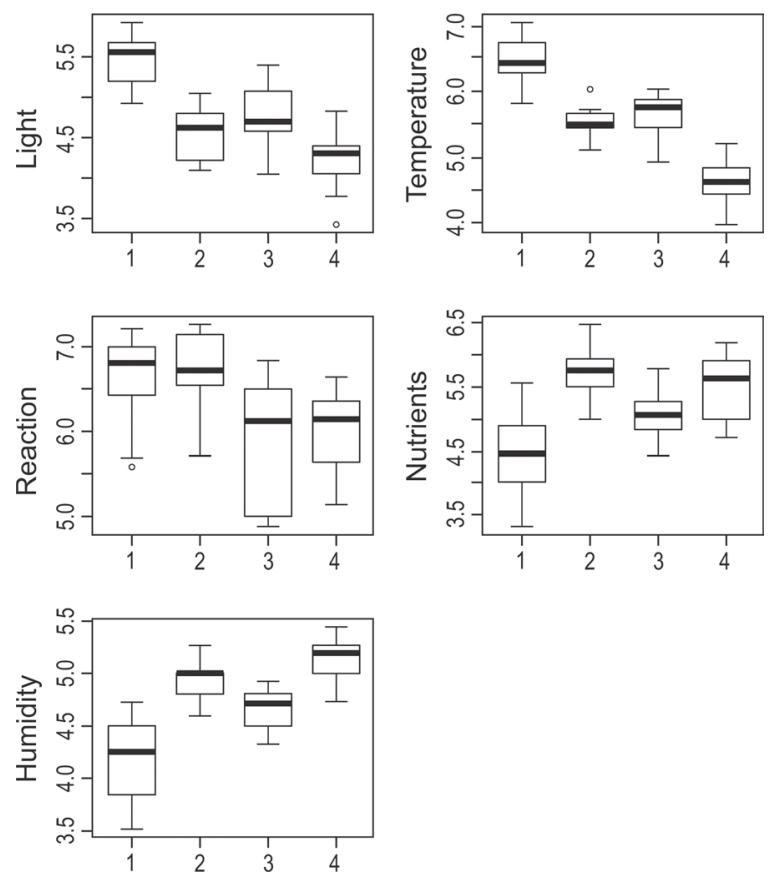

Figure 6. Box-plots of Pignatti bioindicator values for light, temperature, reaction $(p H)$, nutrients and humidity. Box plots present median, interquartile range, maximum, minimum and outliers. Legend: numbers on y axis present mean bioindicator values, samples are grouped as in Fig. 5. 


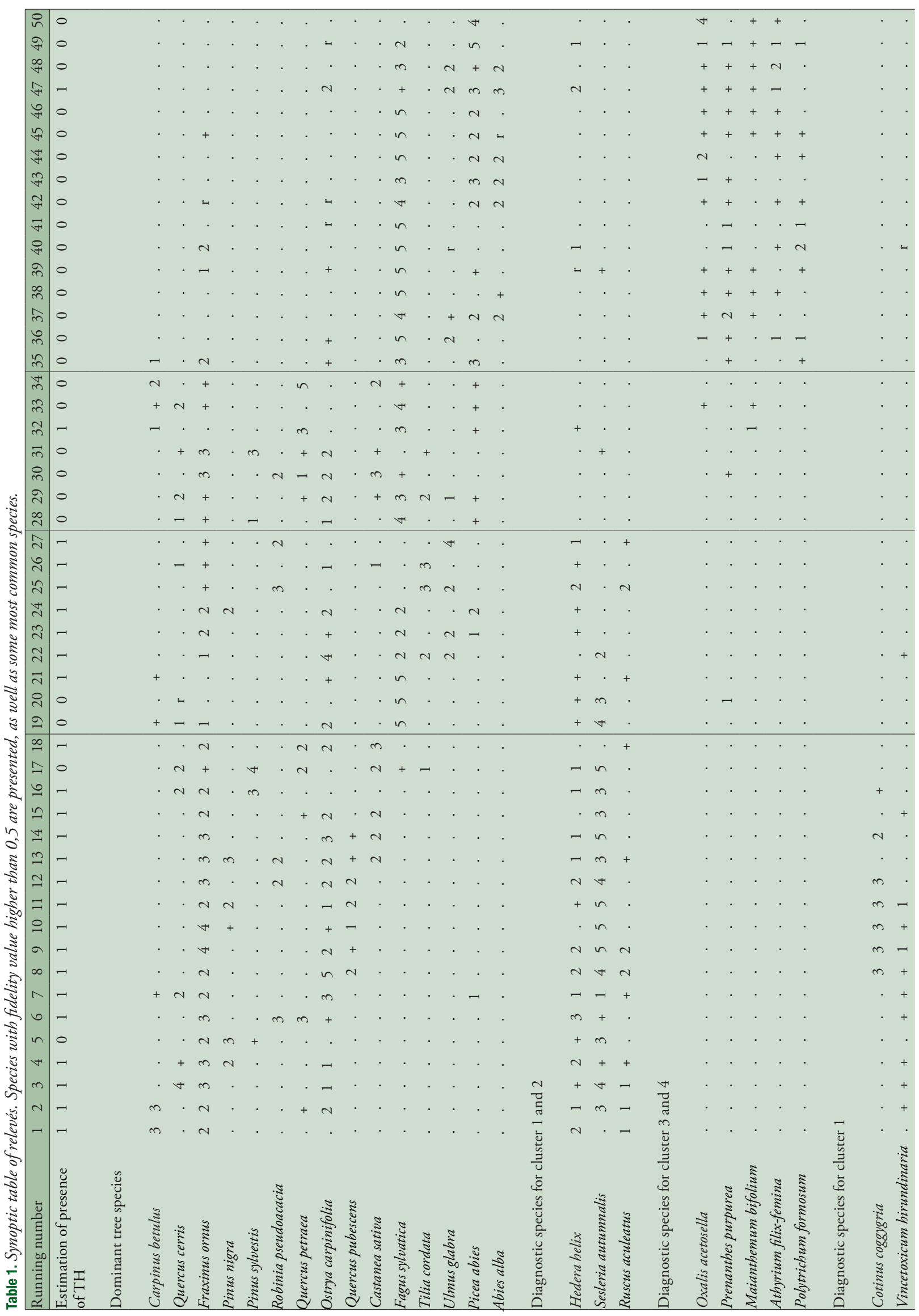




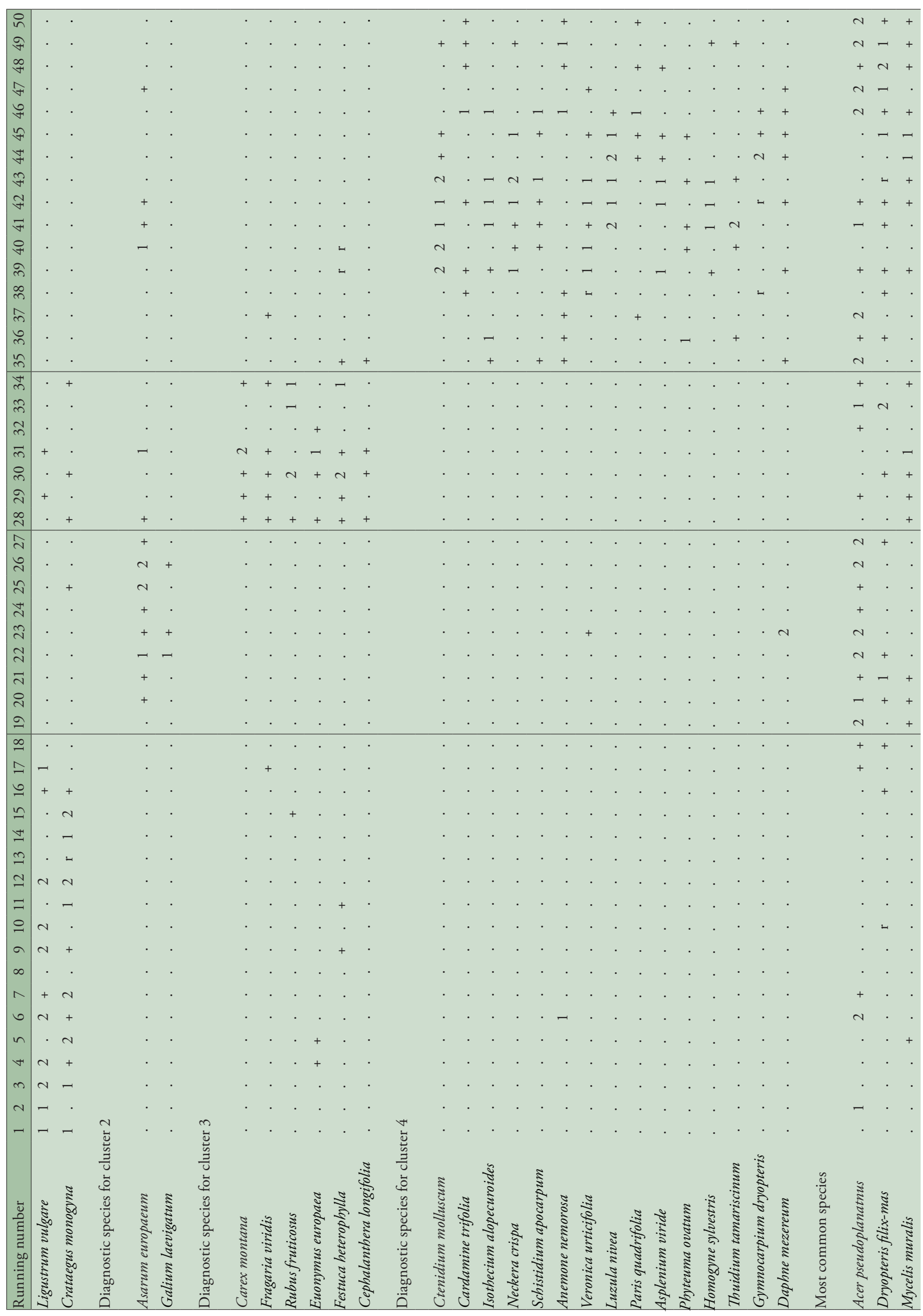




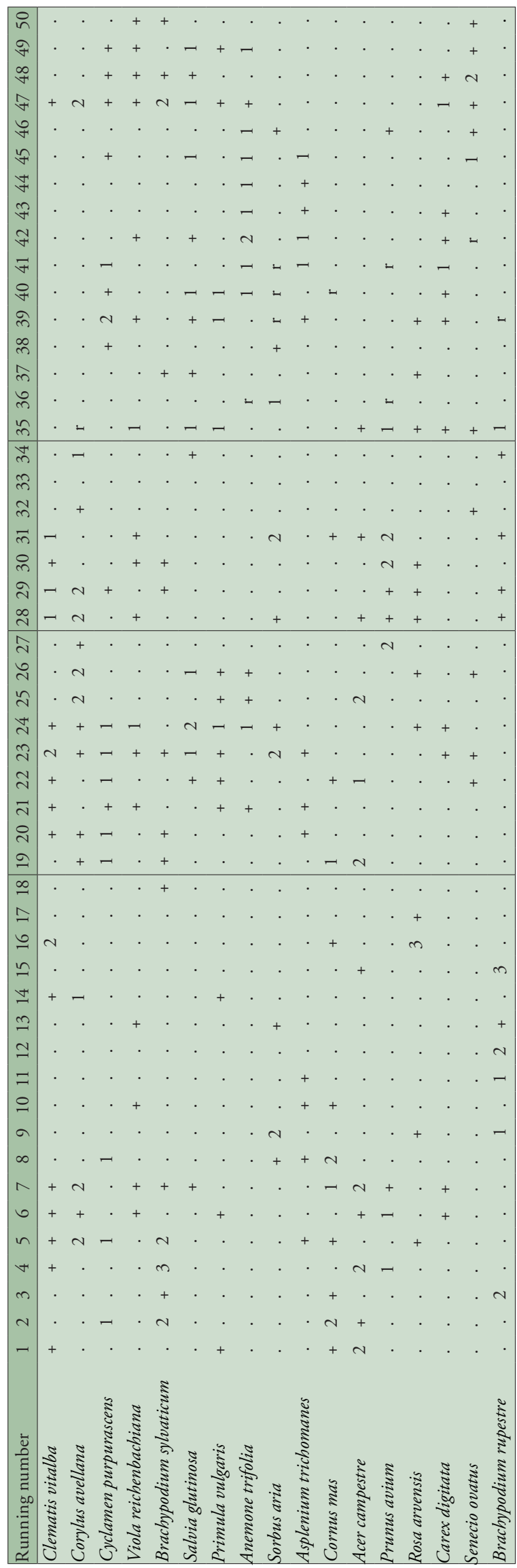

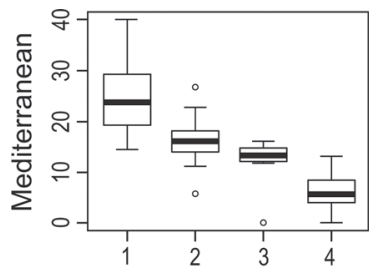
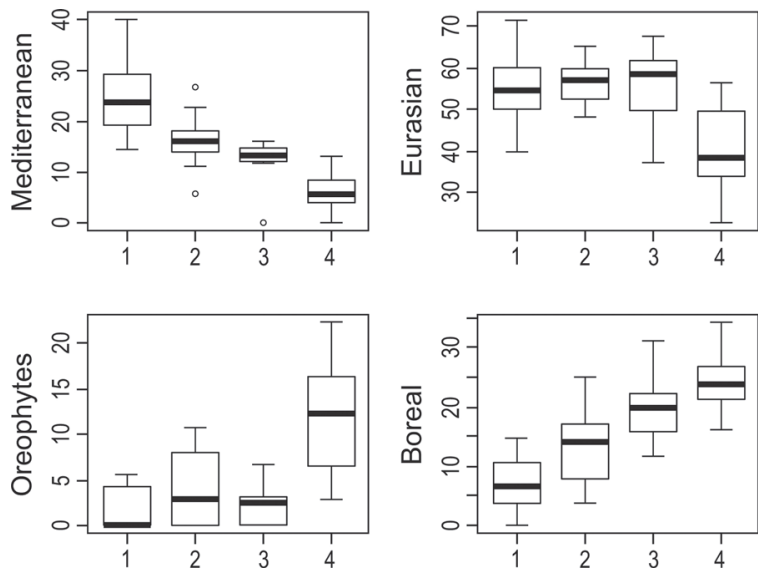

Figure 7. Box-plots of origin of species (chorotypes) in each group. Legend: numbers on y axis present percentage of each chorotype, samples are grouped as in Fig. 5.
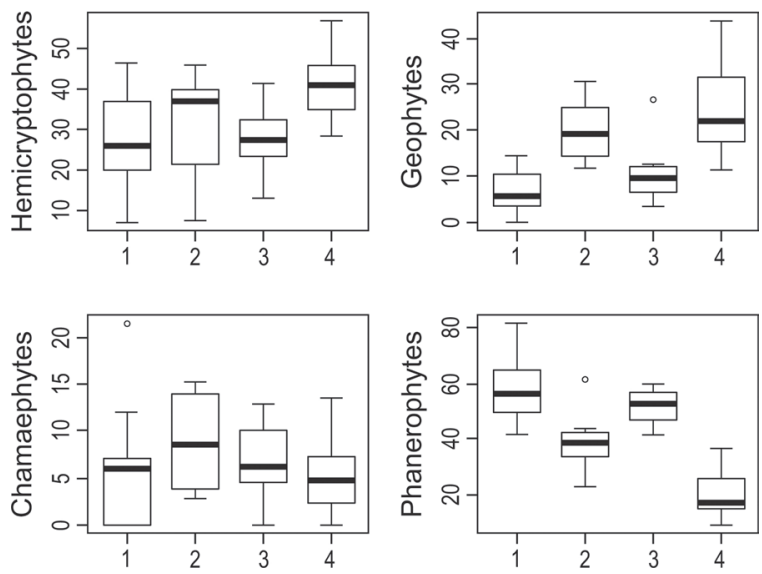

Figure 8. Box-plots of morphological functional types. Therophytes are not present in most of samples (76\%) in the other they have a minor presence. Legend: numbers on y axis present percentage of morphological functional types, samples are grouped as in Fig. 5.

Morphological functional types (Raunkier's life forms) (Fig. 8) show that there are more phanerophytes in polidominant (sub)Mediterranean forests and more hemicryptophytes and geophytes in montane forests.

Ecological strategies (Fig. 9) show that most of plots are situated in the CS part of the CSR space. The separation of relevés in the plot is hardly possible, but we can detect more plots from cluster 1 and 2 with more pronounces competitor strategy and cluster 3 and 4 with more stress tolerators.

Social behavioral types (Fig. 10) show the predominance of species from thermophilous deciduous forest, forest edges and grassland communities in the (sub)Mediterranean influenced forests in cluster 1; clusters 2 and 3 are in-between, and cluster 4 is dominated by species of mesophilous and acidophilous forests. 


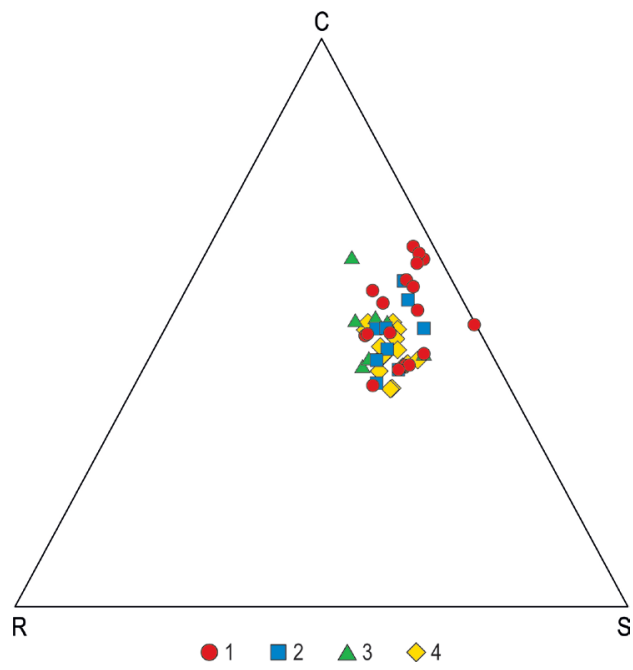

Figure 9. CSR diagram with ecological functional types. Position of the section in the CSR triangle is presented in the upper right side. Legend: see Fig. 5.
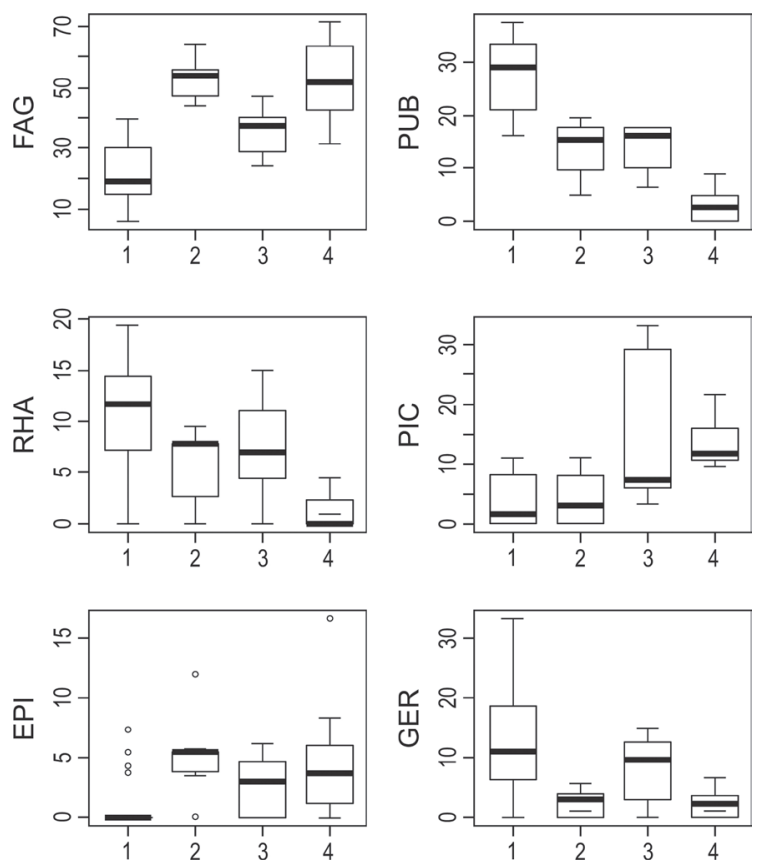

Figure 10. Box-plots of social behavioral types. Legend: FAG-species of mesophilous forests, PUB - species of thermophilous deciduous forests, RHA - shrub and mantle species, PIC-species of acidophilous forests, EPI species of forest clearings, GER - species of forest edges and dry grasslands. Numbers on y axis present percentage of each social behavioral type, samples are grouped as in Fig. 5.

\section{DISCuSSION}

Analysis of present occurrence showed that a dense population of TH can be found only in the western part of Slovenia, which is under the influence of the Mediterranean Sea. The situation is similar in neighboring Croa- tia (48-49). In this area, TH has settled all appropriate niches, whereas in central and eastern, more continental parts of the country, it can be found only along transport networks and rivers, which are the main drivers for the spread of $\mathrm{TH}(8,50)$. In this part, $\mathrm{TH}$ invasion has remained in the lag phase for 150 years since its arrival in Slovenia $(9,14)$. It is important to survey TH in the future in those areas, in part because expected global warming will cause Mediterranean-like changes of the climate (51) and faster expansion of invasive species can be expected (52).

TH appears in the areas close to the Adriatic Sea. It also appears on the karstic plateau, with more pronounced summer hydric stress (precipitation seasonality), but does not appear above an altitude of 655 meters. The lower temperature seasonality excludes the hilly region of $\mathrm{Br}-$ kini, lying at lower altitudes in the hinterland. $\mathrm{TH}$ is also distributed along the alpine rivers, which allow the flow of warm air. The appearance in the Bovec region is the result of planting in the past but the mild and humid local climate apparently suits it. Slope is of a local character and is decisive for the appearance of TH on a smaller scale in the transitional area.

The classification and ordination diagram with passively projected indicator values shows that the main division is on the axis light - moisture, whereby dry and light (sub)Mediterranean forests classified within the cluster 1, susceptible for invasion by $\mathrm{TH}$, are on the one side and humid and closed, less vulnerable forests of cluster 4 on the other. This division can be explained by climatic separation. TH spreads along the gradient from Mediterranean areas towards the continent. Just as in the Mediterranean area the distribution of $\mathrm{TH}$ is mainly affected by site fertility, in the continental parts of Europe climate is decisive (6). However, in the transitional zone the appearance is influenced by other factors of a more local character (e.g. soil) (53).

Light is certainly one of the crucial factor that enable the invasion of $\mathrm{TH}$. $\mathrm{TH}$ is one of the species that participate in afforestation of abandoned grasslands. At the same time it can be expected also in young forest (e.g. in pole stage), but our research was focused on established forests (11). At the same time it should also be taken in consideration that the closure of canopy is different between oak, beech and spruce tree (54), but it corresponds to the forest type. There exists an interrelation between climate, forest type and light availability at herb layer.

$\mathrm{TH}$ is expected to invade more intensively hornbeam, black and scots pine forests, as well as turkey and sessile oak forests and pubescent oak and hop-hornbeam forests. It can also easily appear in submontane and thermophilous beech forests and in ravines. Invasion is less likely in acidophilous sessile oak, chestnut and scots pine forests and in montane beech, Norway spruce and silver fir forests. (55-60). The riverine forest dominated by Alnus 
glutinosa that was eliminated from the analysis can also be added to the group of susceptible communities. This stand was sampled within the area susceptible to $\mathrm{TH}$ invasion. Riverine forests from other regions have already been recognized as vulnerable (61).

The ecological bioindicator values (43) show two extremes, cluster 1 is characterized by high light and temperature and low humidity and nutrients, and vice versa for cluster 4 . Clusters 2 and 3 are in an intermediate position. $\mathrm{TH}$ is drought resistant (62) and does not tolerate shading (11). It seems that nutrients do not have an important role (6). The only exception in the case of indicator values is the $\mathrm{pH}$ of the soil, moderately alkaline soil can be found within clusters 1 and 2, which are more susceptible to $\mathrm{TH}$ invasion, and neutral $\mathrm{pH}$ indicator values in clusters 3 and 4, which are less vulnerable to invasion. It can be concluded that $\mathrm{TH}$ is a good competitor on shallow soils on carbonate bedrock (63).

The analysis of chorotypes confirmed the (sub)Mediterranean origin of the species (3). In forests from susceptible clusters 1 and 2, a higher proportion of Mediterranean and Eurasian elements can be found, whereas clusters 3 and 4 show a higher proportion of boreal species and species from SE European Mountains.

Morphological life strategies reflect to a major extent the climatic conditions (64) and therefore more phanerophytes can be found in polidominant (sub)Mediterranean forests and more hemicryptophytes in the more mesic forests of cluster 4 . More geophytes can be found in mesic sites on carbonate bedrock (65-66).

As all here observed tree species has $\mathrm{C}$ strategy in database (44), this would mask eventual differences, we calculated the CSR signature only on the basis of the herb layer (67). The position of the CSR signature is close to the CS axis, which means that these communities are final stages of development. More competitors can be found in cluster 1 and more stress tolerant and ruderal species in the other three clusters. The higher proportion of the latter strategies is caused by shading in closed stands and human impact in more productive forests (68-69). We could not find reasons for vulnerability from the ecological signature. It has already been established that TH can invade initial successional stages and forest gaps and clearings, in which the ruderal signature is much more pronounced (69).

Social behavioral type shows the predominance of species from thermophilous forests, shrubby species and species from forest edges and dry grasslands in cluster 1 and partially also in clusters 2 and 3, whereas cluster 4 is dominated by species of mesophilous and acidophilous forests. A difference between clusters 2 and 3 is recognizable and coincides with the bioindicator value for soil $\mathrm{pH}$ (soil reaction). In communities from clusters 1 and 2, which are susceptible to invasion of $\mathrm{TH}$, a low proportion of species from acidophilous forests can be found. These species do not appear on shallow soils on carbonate bedrock and create a difference with communities of cluster 3 (and 4) appearing on deep, decalcified soils (70-71).

Our research, which forecasts the future distribution of $\mathrm{TH}$ in the studied region, will offer the basis for the preparation of measures to prevent its spread. Such procedures are common in other parts of the world (72), although it is also necessary to take into consideration the opinion of Brus et al. (73), who thinks that we must reconsider our perception of TH and to accept it as part of our natural environment.

\section{CONCLUSION}

Dense populations of TH can be found only in the western part of Slovenia, whereas in central and eastern Slovenia TH appears only sporadically, mostly along rivers.

We found that the main factor that initiates the invasion of $\mathrm{TH}$ on a larger scale are macro-climatic conditions, and site conditions on a smaller scale. In the research area, the main factor for the appearance of $\mathrm{TH}$ is the influence of the Mediterranean climate on a larger scale and deep, decalcified soils on a smaller one.

$\mathrm{TH}$ can be expected in sub-Mediterranean lowland hornbeam forest, secondary black and scots pine forests, turkey oak forests, sessile oak forests and pubescent oak and hop-hornbeam forests as well as in submontane and thermophilous beech forests and in ravine forests. Forests that are less susceptible to $\mathrm{TH}$ invasion are montane beech forests, chestnut forests, sessile oak forests, scots pine forests and forests dominated by beech, Norway spruce and silver fir.

\section{Acknowledgement}

We owe thanks to Zvone Sadar, Branko Vreš, Andrej Seliškar, Mladen Prebevšek, Matej Reščič, Zoran Zavrtanik, Brane Anderle and Branko Dolinar for providing field data about the appearance of TH. Iztok Sajko kindly prepared the illustrations. The research was part of the project, Planning and silvicultural intervention in situations of the presence of alien invasive tree species (V41431), funded by the Slovenian Research Agency and the Ministry of the Republic of Slovenia for Agriculture, Forestry and Food. We would like to thank Sven Jelaska and two unknown reviewers for constructive comments and suggestions on previous versions of the manuscript.

\section{REFERENCES}

1. MARTINČIČ A. 2007 Mala flora Slovenije. Ključ za določanje praprotnic in semenk. Tehniška založba Slovenije, Ljubljana.

2. ROSS RM, MAZIMPAKA V, ABOU-SALAMA U et al 2013 Mosses of the Mediterranean, an annotated checklist. Crypt Bryol 34 (2): 99-283. https://doi.org/10.7872/cryb.v34.iss2.2013.99 
3. HU SY 1979 Ailanthus. Arnoldia 39: 29-50.

4. BRUS R, DAKSKOBLER I 2001 Visoki pajesen. Proteus 63: 224-228.

5. HULME PE, NENTWIG W, PYŠEK P, VILÀ M 2010 DAISIE: Delivering alien invasive species inventories for Europe In: Settele et al. Atlas of Biodiversity in Europe. Pensoft, Sofia, pp: 134-135.

6. KOWARIK I 1983 Zur Einbürgerung und zum pflanzengeographischen Verhalten des Götterbaumes (Ailanthus altissima (Mill.) Swingle) im französischen Mittelmeergebiet (Bas-Languedoc). Phytocoenologia 11: 389-405.

https://doi.org/10.1127/phyto/11/1983/389

7. DAKSKOBLER I 2003 Floristične novosti iz Posočja in sosednjih območij v zahodni Sloveniji - III. Hladnikia 15-16: 43-71.

8. KOWARIK I, SÄUMEL I 2007 Biological flora of Central Europe: Ailanthus altissima (Mill.) Swingle. Perspecives Plant Ecol Evol Syst 8: 207-237. https://doi.org/10.1016/j.ppees.2007.03.002

9. BRUS R, GAJŠEK D 2014 The introduction of non-native tree species to present day Slovenia. In: Štih P, Zwitter $\check{Z}$ (eds) Man, nature and environment between the northern Adriatic and the eastern Alps in premodern times. Znanstvena založba Filozofske fakultete, Ljubljana, pp 380-392.

10. CHYTRÝ M, MASKELL LC, PINO J et al 2008 Habitat invasions by alien plants: a quantitative comparison among Mediterranean, subcontinental and oceanic regions of Europe. J Appl Ecol 45: 448-458. https://doi.org/10.1111/j.1365-2664.2007.01398.x

11. KNAPP LB, CANHAM CD 2000 Invasion of an old-growth forest in New York by "Ailanthus altissima": sampling growth and recruitment in canopy gaps1. J Torrey Bot Soc 127: 305-315. https://doi.org/10.2307/3088649

12. VUKOVIĆ N, MILETIĆ M, MILOVIĆ M, JELASKA SD 2014 Grime's CRS strategies of the invasive plants in Croatia. Period Biol 166(3): 323-329.

13. KOWARIK I 1995 Clonal growth in Ailanthus altissima on natural site in West Virginia. J Veg Sci 6: 853-856. https://doi.org/10.2307/3236399

14. PYŠEK P, RICHARDSON DM 2012 Invasive species. In: Craig RK, Nagle JC, Pardy B, et al. (eds) Ecosystem Management and Sustainability. Berkshire Publishing Group, Great Barrington, MA, pp 211-219.

15. KUMSCHICK S, GAERTNER M, VILÀ M et al 2015 Ecological impacts of alien species: quantification, scope, caveats, and recommendations. BioScience 65: 55-63.

https://doi.org/10.1093/biosci/biu193

16. DRENOVSKY RC, GREWELL BJ, D'ANTONIO CM, et al 2012 A functional trait perspective on plant invasion. Ann Bot 100: 141-153. https://doi.org/10.1093/aob/mcs100

17. RICCIARDI A, HOPPES MF, MARCHETTI MP, LOCKWOOD JL 2013 Progress toward understanding the ecological impacts of nonnative species. Ecol Monogr 83: 263-282. https://doi.org/10.1890/13-0183.1

18. PYŠEK P, JAROŠŚK V, HULME PE et al 2012 A global assessment of invasive plant impacts on resident species, communities and ecosystems: the interaction of impact measures, invading species' traits and environment. Glob Change Biol 18: 1725-1737. https://doi.org/10.1111/j.1365-2486.2011.02636.x

19. DUCKWORTH JC, KENT M, RAMSAY PM 2000 Plant functional types: an alternative to taxonomic plant community description in biogeography? Prog Phys Geogr 24: 515-542. https://doi.org/10.1191/030913300701542778

20. ŠKORNIK S, HARTMAN K, KALIGARIČ M 2010 Relation between CSR functional signatures of dry grasslands from two contrasting geological substrates. Ann Ser Hist Nat 20: 101-112.
21. SHIPLEY B 2010 From plant traits to vegetation structure: chance and selection in the assembly of ecological communities, Cambridge University Press. Cambridge, UK.

22. RAUNKIAER C 1934 The life forms of plants and statistical plant geography. Oxford University Press, Oxford, UK

23. GRIME JP 2001 Plant strategies, vegetation processes, and ecosystem properties, $2^{\text {nd }}$ edition, Wiley. New York.

24. HUNT R, HODGSON J, THOMPSON K et al 2004 A new practical tool for deriving a functional signature for herbaceous vegetation. Appl Veg Sci 7: 163-170.

https://doi.org/10.1111/j.1654-109X.2004.tb00607.x

25. SELIŠKAR T, VREŠ B, SELIŠKAR A 2003 FloVegSi 2.0. Računalniški program za urejanje in analizo bioloških podatkov. Biološki inštitut ZRC SAZU.

26. ŠILC U 2012 Vegetation Database of Slovenia. Biodiv Ecol 4: 428428. https://doi.org/10.7809/b-e.00215

27. INSTITUTE OF THE REPUBLIC OF SLOVENIA FOR NATURE CONSERVATION / Zavod Republike Slovenije za varstvo narave 2016 Available habitat maps (http://www.zrsvn.si, approach 1. 7. 2016).

28. KUTNAR L, KOBLER A 2013 Sedanje stanje razširjenosti robinije (Robinia pseudoacacia L.) v Sloveniji in napovedi za prihodnost. Acta silvae et ligni 102: 21-30.

29. RIBEIRO D, SOMODI I, ČARNI A 2016 Transferability of a predictive Robinia pseudacacia distribution model in northeast Slovenia. Acta Geogr Slov 56: 25-43. https://doi.org/10.3986/AGS.772

30. GEOLOGICAL SURVEY OF SLOVENIA / Geološki zavod Slovenije 2003 Osnovna geološka karta Slovenije, Ljubljana.

31. SURVEYING AND MAPPING AUTHORITY OF THE REPUBLIC OF SLOVENIA / Geodetska uprava Republike Slovenije 2009 Državna topografska karta 1: 5000, Ljubljana.

32. MINISTRY OF AGRICULTURE, FORESTRY AND FOOD / Ministrstvo za kmetijsto, gozdarstvo in prehrano 2007 Pedološka karta Slovenije $1: 25.000$, Ljubljana.

33. HIJMANS RJ, CAMERON SE, PARRA JL, et al 2005 Very high resolution interpolated climate surfaces for global land areas. Int J Climatol 25:1965-1978. https://doi.org/10.1002/joc.1276

34. DEBELJAK M, FICKO A, BRUS R 2015 The use of habitat and dispersal models in protecting European black poplar (Populus nigra L.) from genetic introgression in Slovenia. Biol Conserv 184: 310-319. https://doi.org/10.1016/j.biocon.2015.02.004

35. HALL M, FRANK E, HOLMES G et al 2009 The WEKA data mining software: an update. SIGKDD Explorations 11(1): 10-18. https://doi.org/10.1145/1656274.1656278

36. MINISTRY OF AGRICULTURE, FORESTRY AND FOOD / Ministrstvo za kmetijstvo, gozdarstvo in prehrano 2016 Raba. Javni pregledovanik grafičnih podatkov MKO.

37. BRAUN-BLANQUET J 1964 Pflanzensoziologie, Grundzüge der Vegetationskunde, 3rd ed. Springer Verlag, Wien. https://doi.org/10.1007/978-3-7091-8110-2

38. HENNEKENS SM, SCHAMINÉE JHJ 2001 TURBOVEG, a comprehensive data base management system for vegetation data. J Veg Sci 12: 589-591. https://doi.org/10.2307/3237010

39. TICHÝ L 2002 JUICE, software for vegetation classification. J Veg Sci 13: 451-453. https://doi.org/10.1111/j.1654-1103.2002.tb02069.x

40. R DEVELOPMENT CORE TEAM $2016 \mathrm{R}$ software, version 3.1 .1 (http://cran.r-project.org, approach 1. 7. 2016).

41. OKSANEN J 2015 Multivariate Analysis of Ecological Communities in R: vegan tutorial (http://cc.oulu.fi/-jarioksa/opetus/metodi/ vegantutor.pdf, approach 1. 7. 2016). 
42. BRUELHEIDE H $2000 \mathrm{~A}$ new measure of fidelity and its application to defining species groups. J Veg Sci 11: 167-178. https://doi.org/10.2307/3236796

43. PIGNATTI S, MENEGONI P, PIETROSANTI S 2005 Valori di bioindicazione delle piante vascolari della flora d'Italia. BraunBlanquetia 39: 1-97.

44. KLOTZ S, KÜHN I, DURKA (eds) 2002 BIOLFLOR - Eine Datenbank zu biologischökologischen Merkmalen der Gefäßpflanzen in Deutschland. Bundesamt für Naturschutz, Bonn.

45. PIGNATTI S. (ed) 1982 Flora d'Italia 1-3. Edagricole, Bologna.

46. MUCINA L, BUELTMANN H, DIERSSEN K et al 2016 Vegetation of Europe: Hierarchical floristic classification system of vascular plant, bryophyte, lichen, and algal communities. Appl Veg Sci 19, Suppl 1:3-264. https://doi.org/10.1111/avsc.12257

47. TROIANI N, TRADELLA FM, MALATESTA L et al 2016 Long-term cropland abandonment does not lead per se to the recovery of semi-natural herb communities deemed habitats of community interest. Acta Bot Croat 75: 226-235.

48. IDŽOJTIĆ M, ZEBEC M 2006 Rasprostranjenost pajasena ( $A i$ lanthus altissima (Mill.) Swinge) i širenje invazivnih drvenastih neofita u Hrvatskoj. Glas šum pok pos izd 5: 315-323.

49. NIKOLIĆ T (ed) 2015 Flora Croatica baza podataka (http://hirc. botanic.hr/fcd). Prirodoslovno-matematički fakultet, Sveučilište u Zagrebu (date of access: 22.10.2017)

50. PLACHUELO G, CATALÁN P, DELGADO JA 2016 Gone with the wind and the stream: Dispersal in invasive species Ailanthus altissima. Acta Oecol 73: 31-37. https://doi.org/10.1016/j.actao.2016.02.006

51. BERGANT K 2007 Projekcije podnebnih sprememb za Slovenijo. Strok Znan Dela 130: 67-86.

52. KNÜSEL $S$, CONEDERA M, RIGLING A et al 2015 A tree-ring perspective on the invasion of Ailanthus altissima in protection forests. For Ecol Manag 354: 334-343.

53. FEKETE G, MOLNÁR Z, MAGYAR I et al 2014 A new framework for understanding Pannonian vegetation patterns: regularities, deviations and uniqueness. Comm Ecol 15: 12-26. https://doi.org/10.1556/ComEc.15.2014.1.2

54. PRETZSCH H 2014 Canopy space filling and tree crown morphology in mixed-species stands compared with monocultures. For Ecol Manag 327: 251-264.

55. ČARNI A, MARINČEK L, SELIŠKAR A, ZUPANČIČ M 2002 Vegetacijska karta gozdnih združb Slovenije $1: 400.00$. ZRC Publishing, Ljubljana.

56. DAKSKOBLER I 2012 Pregled bukovih rastiščv Sloveniji. In: Bončina A (ed) Bukovi gozdovi v Sloveniji: ekologija in gospodarjenje. Oddelek za gozdarstvo in obnovljive gozdne vire, Biotehniška fakulteta, Ljubljana, pp 58-74.

57. DAKSKOBLER I, KOŠIR P, KUTNAR L 2013a Gozdovi plemenitih listavcev v Sloveniji: združbe gorskega javorja, gorskega bresta, velikega jesena, ostrolistnega javorja, lipe in lipovca. Silva Slovenica, ZGDS-Gozdarska založba, Ljubljana.

58. DAKSKOBLER I, KUTNAR L, ŠILC U 2013b Poplavni, močvirni in obrežni gozdovi v Sloveniji : gozdovi vrb, jelš, dolgopecljatega bresta, velikega in ozkolistnega jesena, doba in rdečega bora ob rekah in potokih. Silva Slovenica, ZGDS-Gozdarska založba, Ljubljana.

59. DAKSKOBLER I, KUTNAR L, ZUPANČIČ M 2014 Toploljubni listnati gozdovi v Sloveniji : toploljubni gozdovi kraškega gabra, puhastega hrasta, gradna, črnega gabra in malega jesena v submediteranskem fitogeografskem območju in ponekod v notranjosti države. Silva Slovenica, ZGDS-Gozdarska založba, Ljubljana.

60. DAKSKOBLER I, KUTNAR L, ROZMAN A 2015 Bazoljubno borovje v Sloveniji : združbe črnega in rdečega bora na karbonatni podlagi in rušja v alpskih dolinah. Silva Slovenica, ZGDS-Gozdarska založba, Ljubljana

61. CASTRO-DÍEZ P, VALLE G, GONZÁLEZ-MUÑOZ et al 2014 Can the life-history strategy explain the success of the exotic trees Ailanthus altissima and Robinia pseudoacacia in Iberian floodplain forests? PLoS ONE 9: e100254

https://doi.org/10.1371/journal.pone.0100254

62. FILIPPOU P, BOUCHAGIER P, SKOTTI E et al 2014 Proline and reactive oxygen/nitrogen species metabolism is involved in the tolerant response of the invasive plant species Ailanthus altissima to drought and salinity. Eviron Exp Bot 97: 1-10. https://doi.org/10.1016/j.envexpbot.2013.09.010

63. TRÁJER A, HAMMER T, BEDE-FAZEKAS Á et al 2016 The comparison of the potential effect of climate change on the segment growth of Fraxinus ornus, Pinus nigra and Ailanthus altissima on shallow, calcareous soils. Appl Ecol Environ Res 14: 161-182. https://doi.org/10.15666/aeer/1403_161182

64. MOLES AT, PERKINS SE, LAFFAN SW et al 2014 Which is a better predictor of plant traits: temperature or precipitation? J Veg Sci 25: 1167-1180. https://doi.org/10.1111/jvs. 12190

65. ČARNI A, MATEVSKI V, JUVAN N, et al 2016 Transition along gradient from warm to mesic temperate forests evaluated by GAMM. J Plant Ecol 9: 410-433. https://doi.org/10.1093/jpe/rtv069

66. VYMAZALOVÁ M, TICHÝ L, AXMANOVÁ I 2016 The role of vernal species in vegetation classification: a case study on deciduous forests and dry grasslands of Central Europe. Phytocoenologia 46: 9-20. https://doi.org/10.1127/phyto/2016/0034

67. PAUŠIČ A, ČARNI A 2013 Functional response traits and plant community strategy indicate the stage of secondary succession. Hacquetia 11: 209-225.

68. GRIME JP 1988 The C-S-R model of primary plant strategies origins, implications and tests. In: Gottlieb LD, Jain SK (eds) Plant evolutionary biology. Chapman and Hall, London, pp 371-393. https://doi.org/10.1007/978-94-009-1207-6_14

69. STUPAR V, ČARNI A 2016 Ecological, floristic and functional analysis of zonal forest vegetation in Bosnia and Herzegovina. Acta Bot Croat 76: 15-26

70. POLDINI L 2009 La diversità vegetale del Carso fra Trieste e Gorizia. Lo stato dell'ambiente. Goliardiche, Trieste.

71. DAKSKOBLER I 2013 Phytosociological characteristics of beech forests in the colline belt of the sub-Mediterranean region of Slovenia. Hrvat Misao 46: 173-189.

72. RADTKE A, AMBRASS S, ZERBE S et al 2013 Traditional coppice forest management drives the invasion of Ailanthus altissima and Robinia pseudoacacia into deciduous forests. For Ecol Manag 291: 308-317.

73. BRUS R, ARNŠEK T, GAJŠEK D 2016 Pomlajevanje in širjenje visokega pajesena (Ailathnus altissima (MillI Swingle) na Goriškem. Gozd Vestn 74: 115-125. 


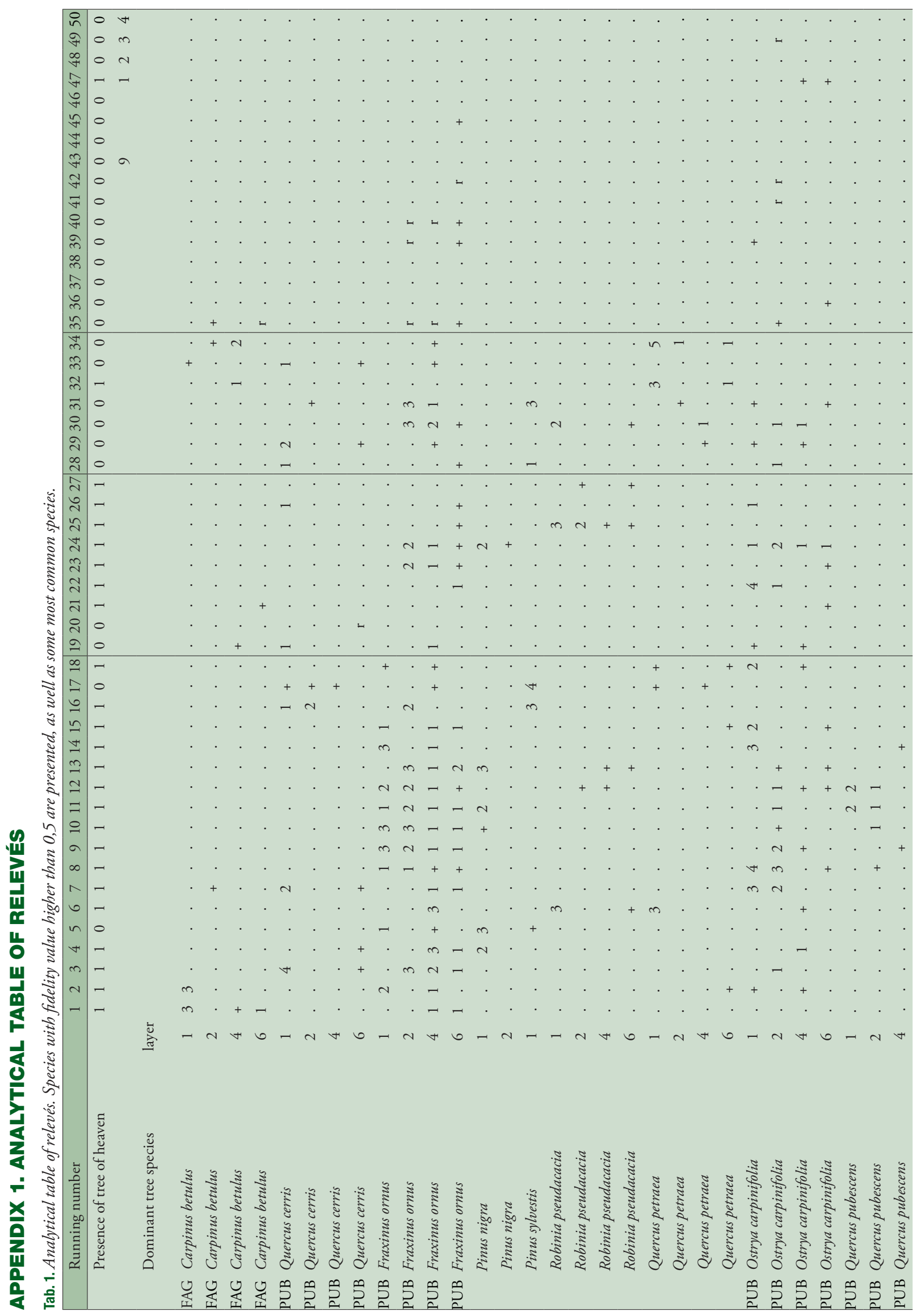




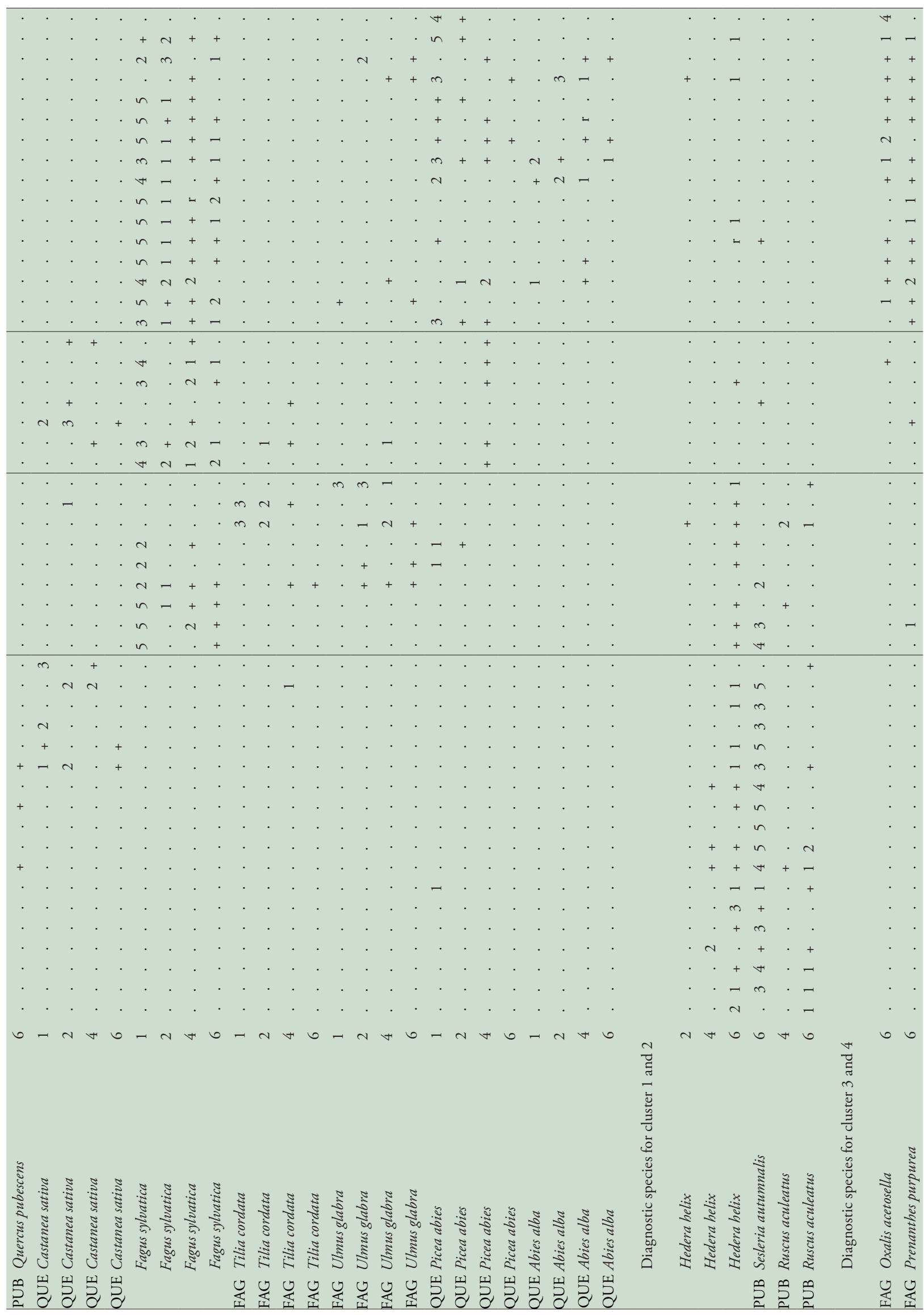




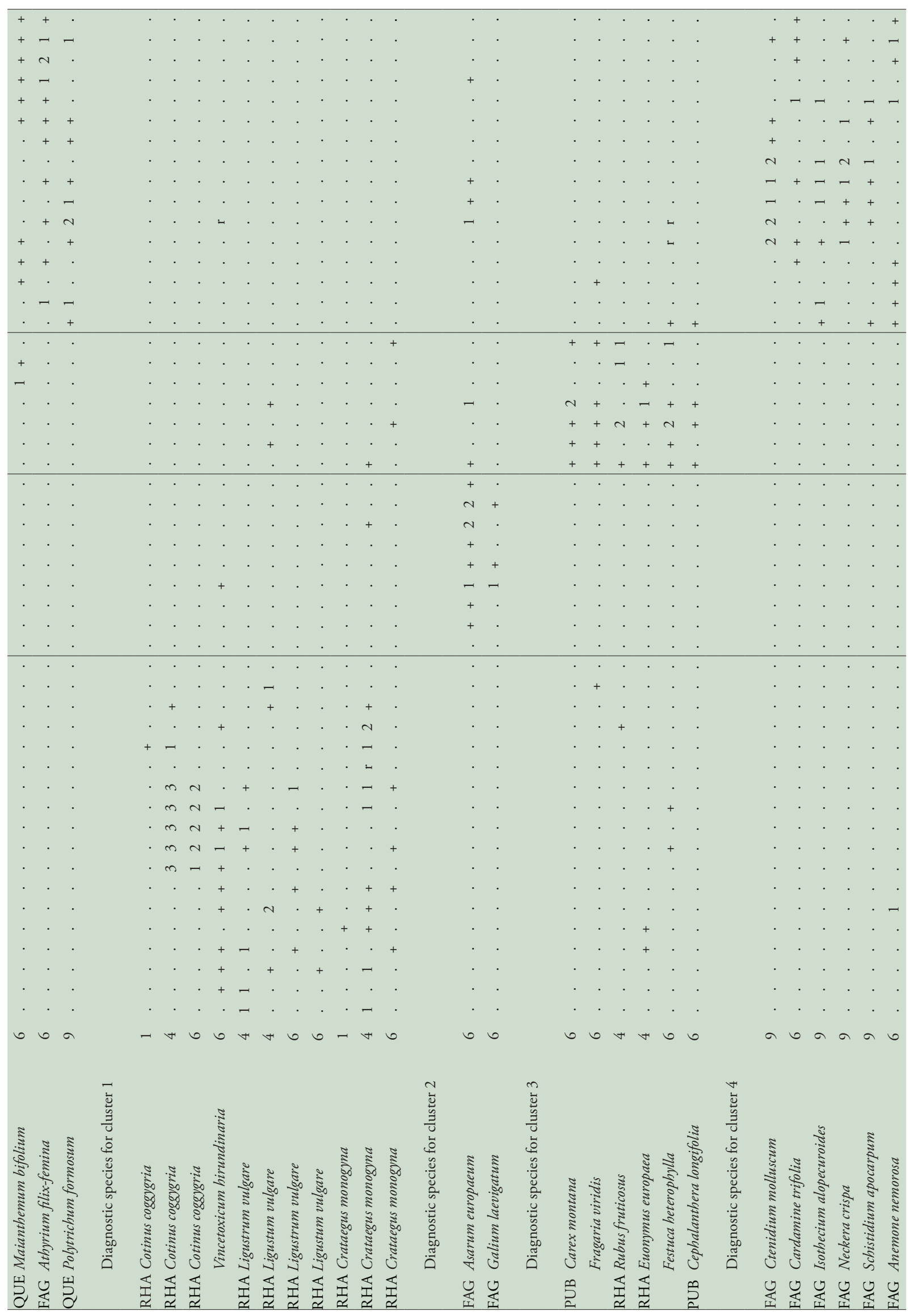




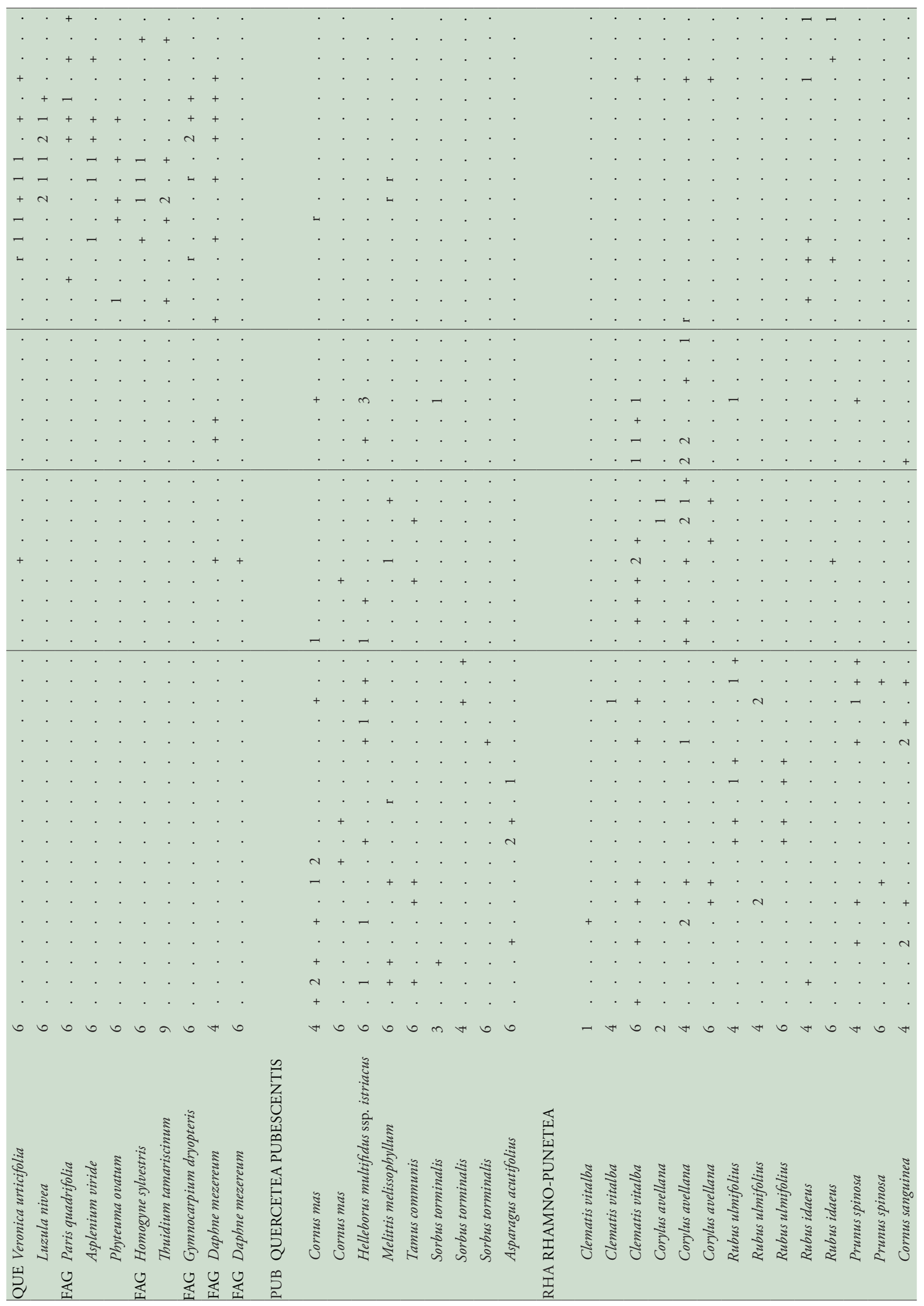




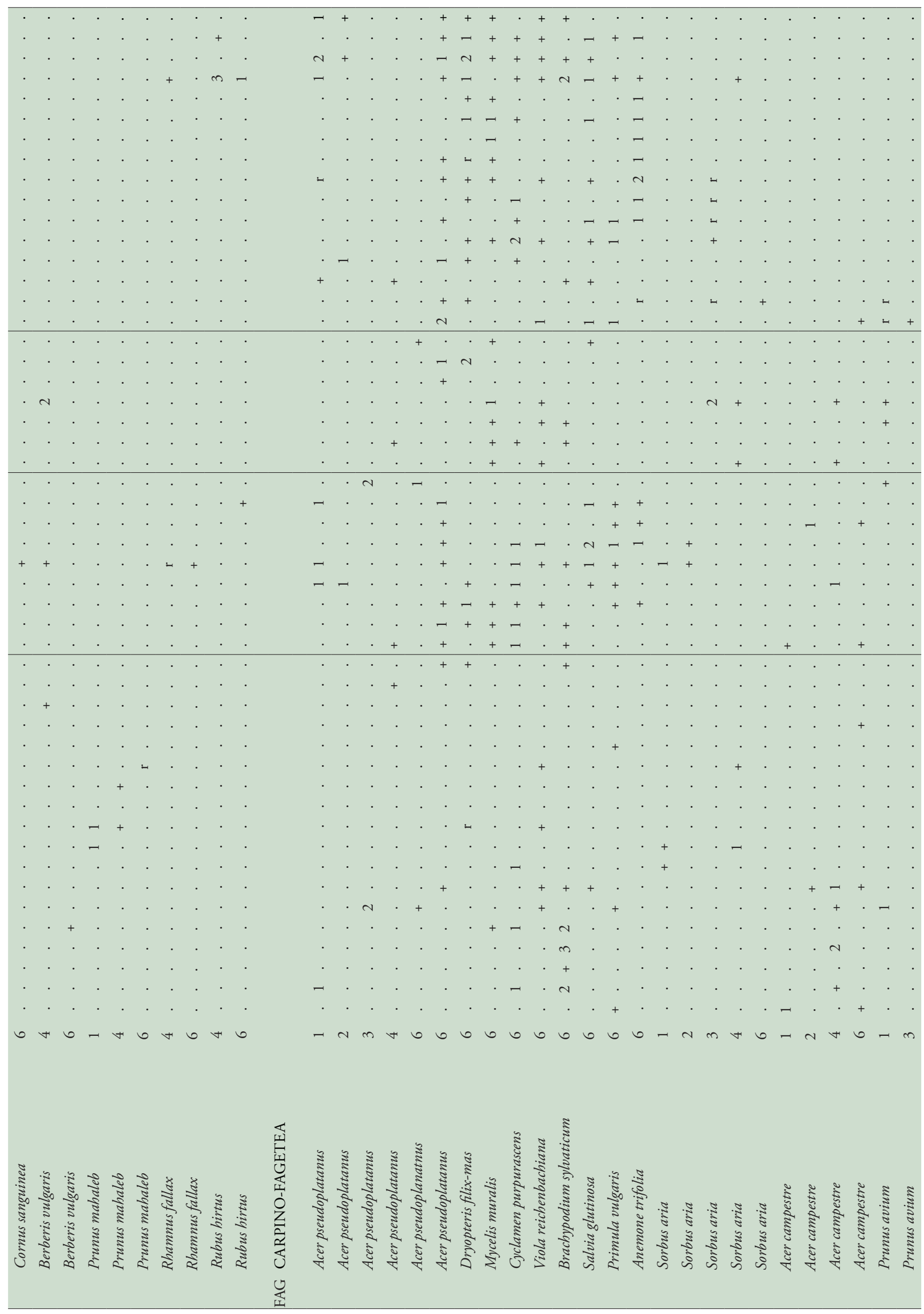




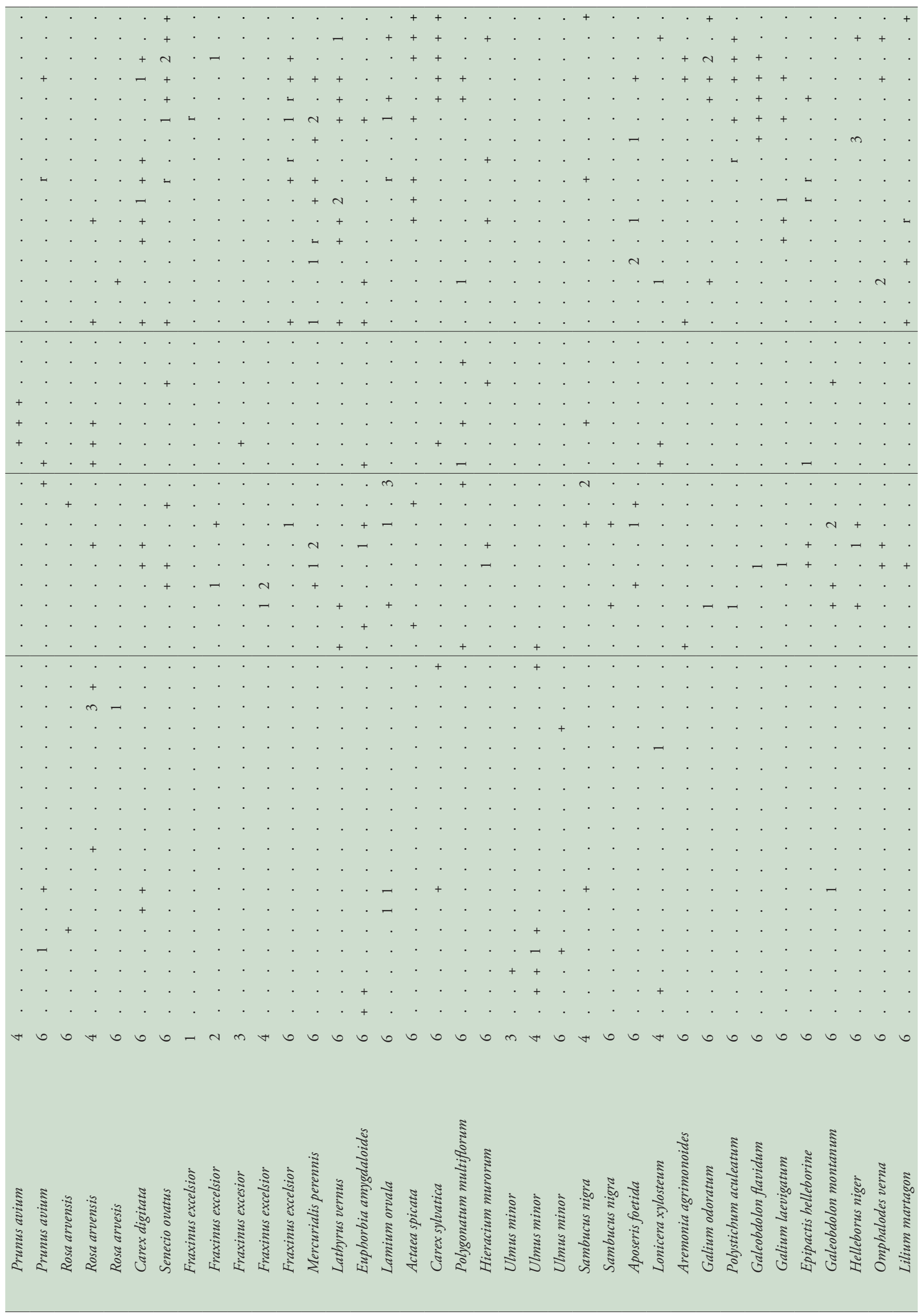




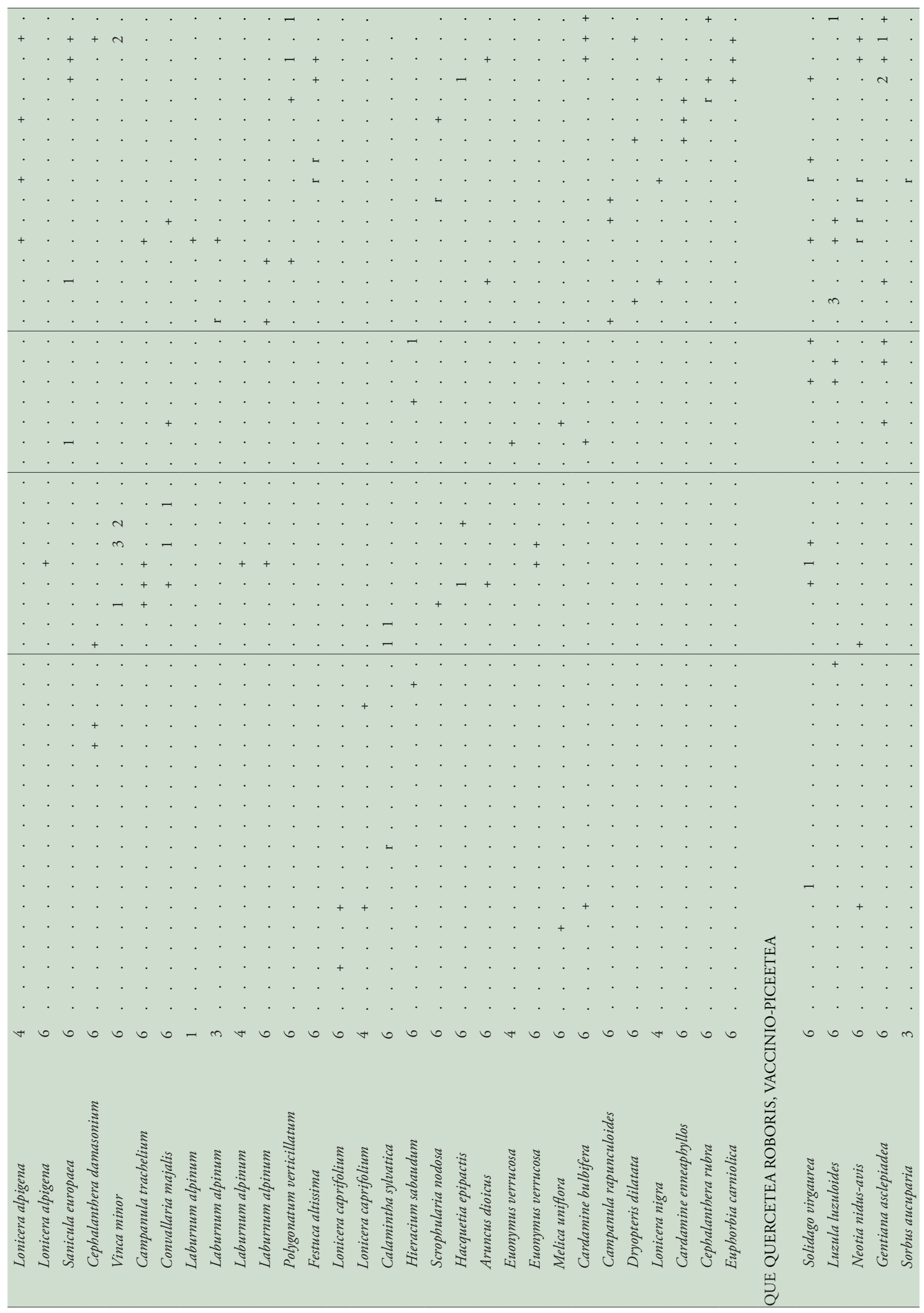




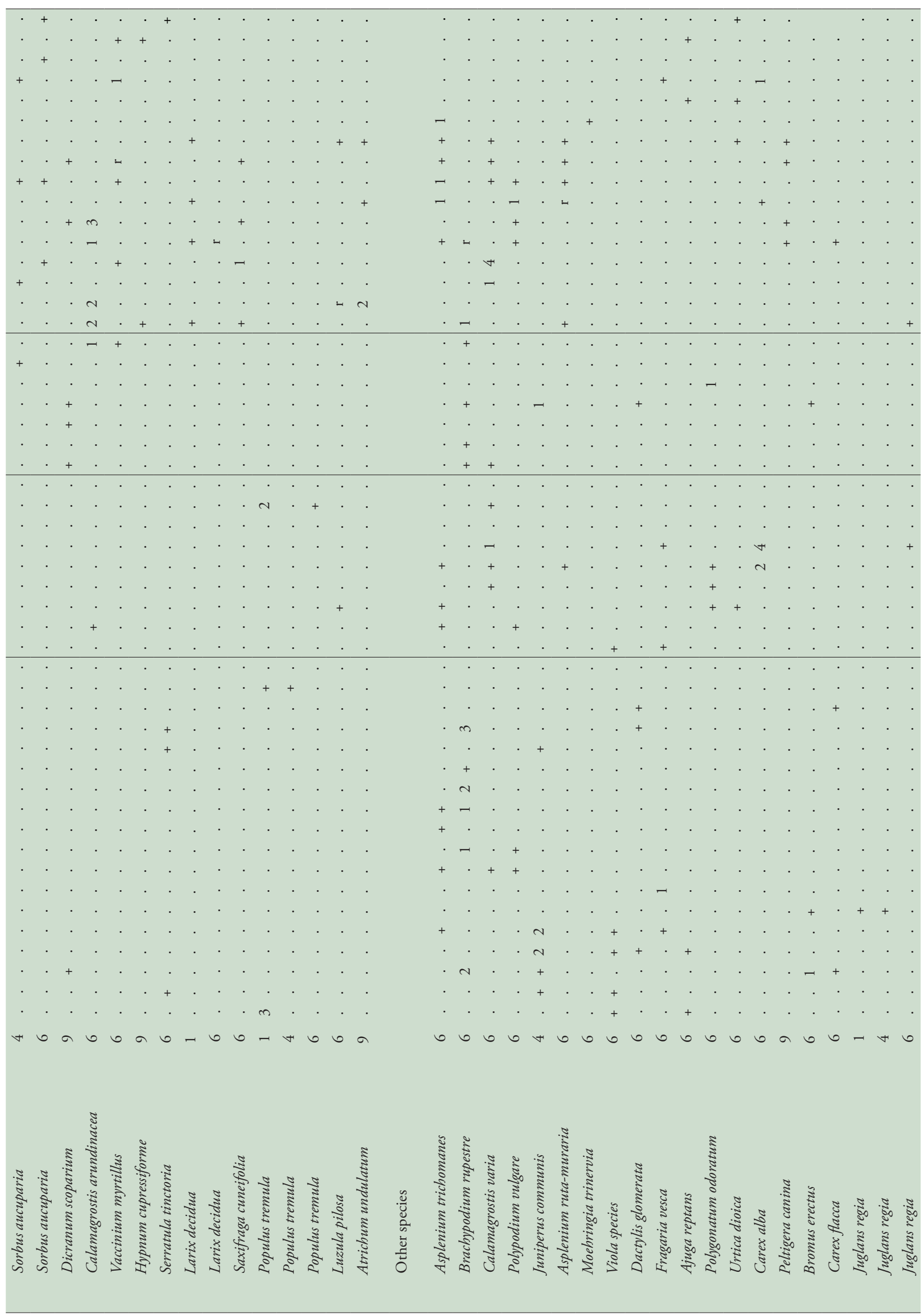




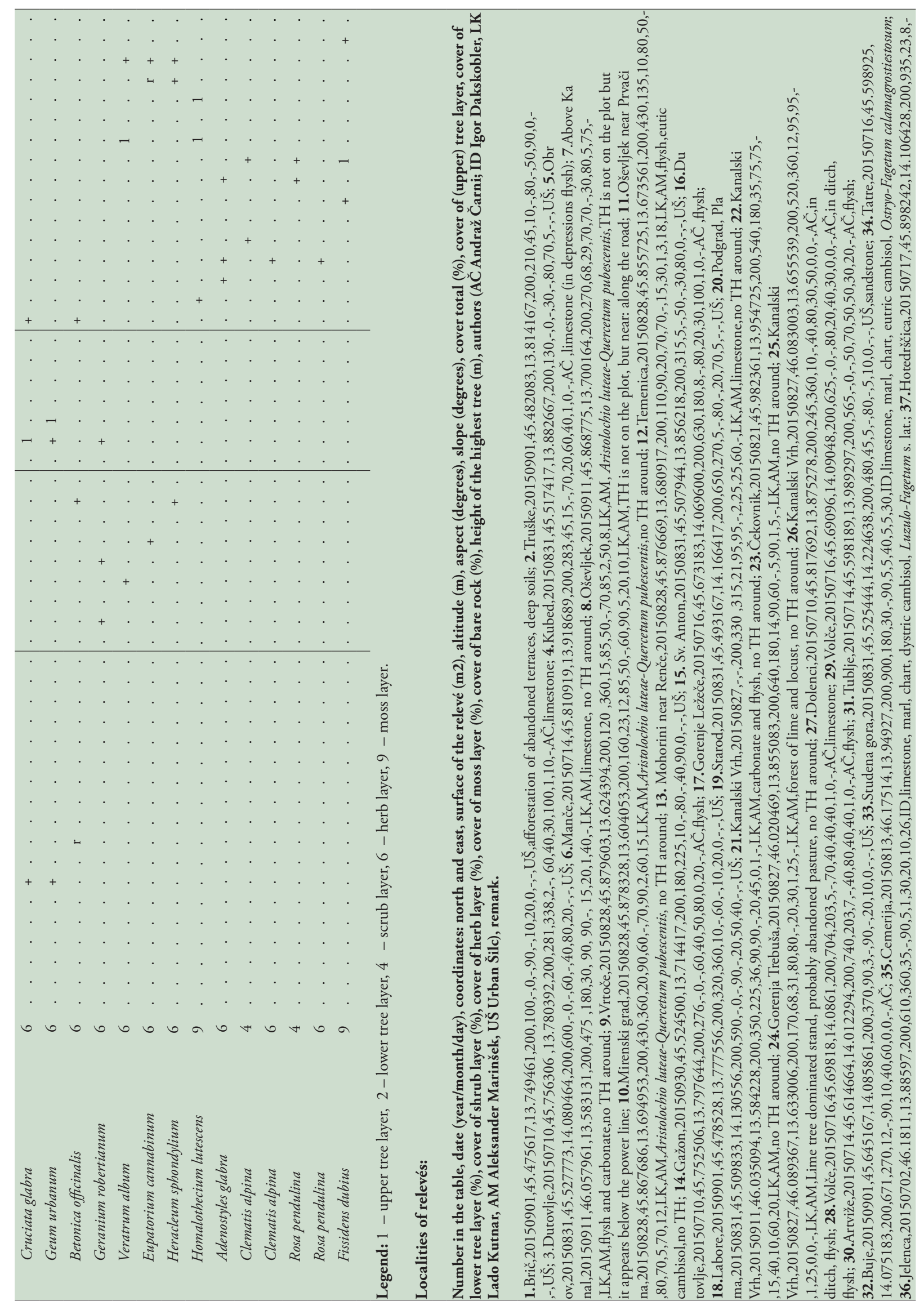




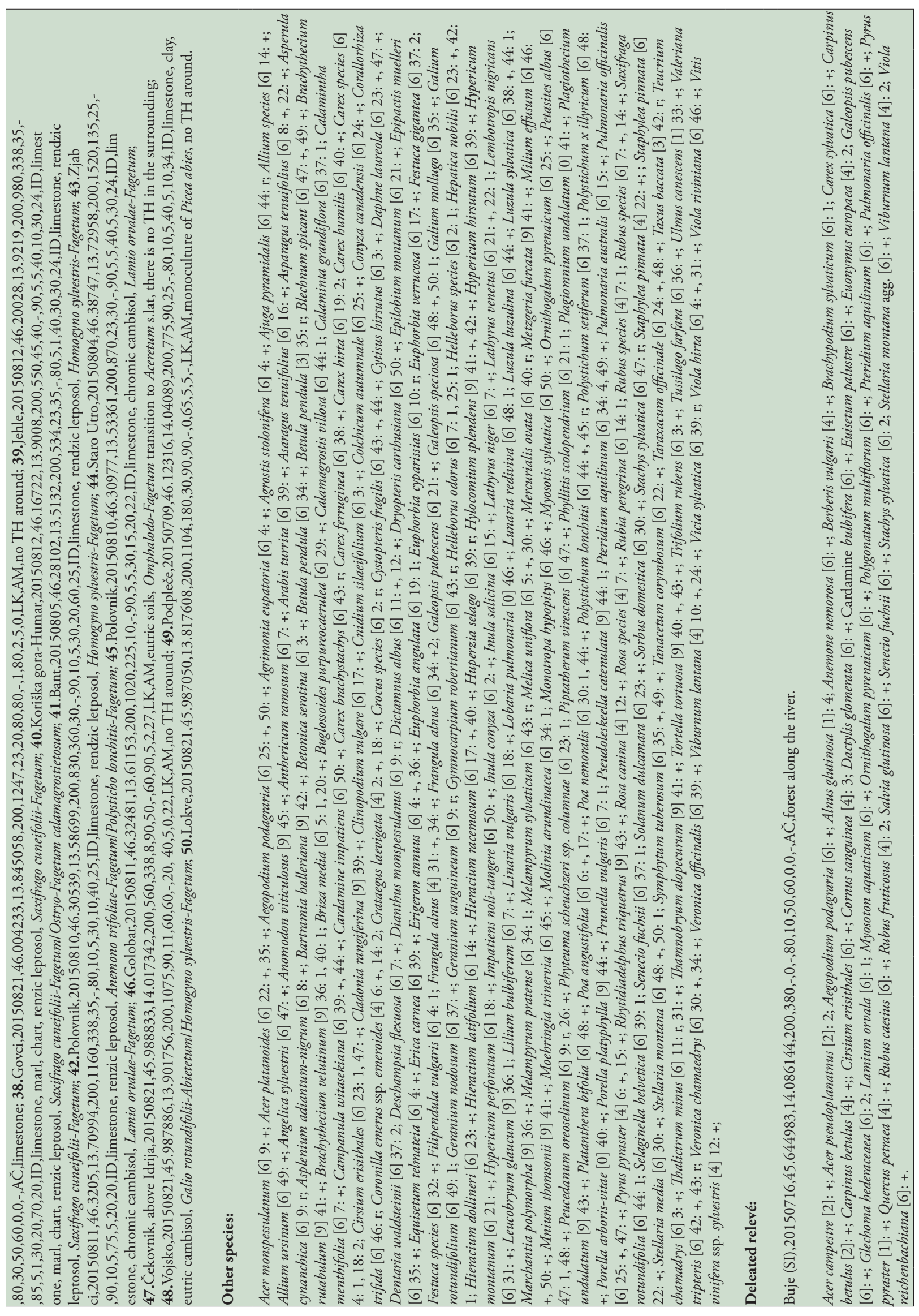

